\title{
The Saxothuringian Terrane affinity of the metamorphic Stachów Complex (Strzelin Massif, Fore-Sudetic Block, Poland) inferred from zircon ages
}

\author{
Teresa OBERC-DZIEDZIC ${ }^{1, *}$, Ryszard KRYZA 1 , Stanisław MADEJ ${ }^{1}$ and Christian PIN $^{2}$ \\ 1 University of Wrocław, Institute of Geological Sciences, 50-205 Wrocław, Plac M. Borna 9, Poland \\ 2 Département de Géologie, CNRS, Université Blaise Pascal, Campus des Cézeaux, 63178 Aubière Cedex, France
}

Oberc-Dziedzic, T., Kryza, R., Madej, S., Pin, C., 2018. The Saxothuringian Terrane affinity of the metamorphic Stachów Complex (Strzelin Massif, Fore-Sudetic Block, Poland) inferred from zircon ages. Geological Quarterly, 62 (2): 237-256, doi: 10.7306/gq.1405

\begin{abstract}
The Saxothuringian Terrane defined in the western part of the Bohemian Massif is regarded to have easterly continuations in the Karkonosze-Izera Massif, the Kamieniec Ząbkowicki Belt and the Orlica-Śnieżnik Dome. All these units comprise Early Ordovician ( $\sim 500 \mathrm{Ma})$ metagranites associated with mica schists. Even more to the east, $\sim 500 \mathrm{Ma}$ metagranites and metasedimentary rocks occur also in the Strzelin Massif of the East Sudetes, where they are known as the pale and dark Stachów gneisses, respectively. Altogether, these rocks form the Stachów Complex which was thrust on the Strzelin Complex of the Brunovistulicum Terrane during the Variscan Orogeny. The contribution presents lines of evidence for a Saxothuringian affinity of the Stachów Complex rocks: (1) the new SHRIMP U-Pb age data of zircons from both the pale and dark Stachów gneisses; (2) the indication that the zircon age spectra from the $\sim 500$ Ma granitoids and their accompanying metasedimentary rocks are similar to those found in other parts of the Sudetes; (3) the "Armorican" age pattern of inherited zircons of the pale Stachów gneisses, as also observed in the Saxothuringian Terrane; (4) the similarity of trace elements and Sm-Nd isotope data of the Stachów gneisses and correlative rocks from the Karkonosze-Izera Massif and the Orlica-Śnieżnik Dome.
\end{abstract}

Key words: Stachów Complex, Saxothuringian Terrane, SHRIMP zircon ages, Strzelin Massif.

\section{INTRODUCTION}

The Bohemian Massif, situated near the eastern termination of the European Variscan belt, comprises a collage of the Moldanubian, Saxothuringian (Kossmat, 1927) and Teplá-Barrandian (Franke, 1989) tectonostratigraphic zones, interpreted as terranes (Matte et al., 1990; Franke and Żelaźniewicz, 2000) of the Armorican Terrane Assemblage (Tait et al., 1997; Franke, 2000), and the western part of the Brunovistulian Terrane (Brunovistulicum, Dudek, 1980), respectively. The Brunovistulicum is separated from the other Bohemian Massif Terranes by the NNE-SSW-striking Moldanubian Thrust Zone (Suess, 1912).

Several tectonostratigraphic units in the Sudetes record the same geological events as in the central segment of the Variscides SW of the Elbe Fault Zone, namely, a late Proterozoic (Cadomian) orogenic event, a Cambro-Ordovician rifting episode accompanied by an important bimodal magmatism, Silurian and Devonian pelagic sedimentation, and, finally, a late Devonian to Early Carboniferous subduction-collision phase,

* Corresponding author, e-mail: teresa.oberc-dziedzic@ing.uni.wroc.pl Received: August 28, 2017; accepted January 10, 2018; first published online: April 17, 2018 documented by Carboniferous synorogenic sedimentation with flysch and olistoliths. These Sudetic units have been regarded as easterly continuations of the Saxothuringian Terrane (Franke and Żelaźniewicz, 2000). Some of them, namely: the Lausitz-Izera Block, the Kamieniec Ząbkowicki Belt and the Orlica-Śnieżnik Dome comprise Early Ordovician ( 500 Ma) metagranites and accompanying mica schists, but the western part of the Lausitz-Izera Block is built of older, $\sim 540 \mathrm{Ma}$ Lusatian granodiorites (Linnemann and Romer, 2002; Białek et al., 2014) which have not been found in the Kamieniec Ząbkowicki Belt and the Orlica-Śnieżnik Dome.

$\mathrm{U}-\mathrm{Pb}$ dating of detrital zircons from the metasedimentary rocks associated with the $\sim 500 \mathrm{Ma}$ orthogneisses in the West and Central Sudetes showed that their ultimate source region was to be found in the West African craton (e.g., Jastrzębski et al., 2010; Žačkova et al., 2012; Mazur et al., 2012, 2015). Such provenance is typical for clastic sediments of the Saxothuringian Terrane (Friedl et al., 2000; Linnemann et al., 2004, 2007).

Age of the youngest detrital zircons put limits on the maximum possible depositional ages of their host sediments and thus provide useful constraints on regional interpretations and larger-scale palaeogeographic reconstructions. These suggest (e.g., Chopin et al., 2012; Mazur et al., 2015) that the Central Sudetes include tectonic units recycled from the subducted Saxothuringian passive margin and may represent an accretionary prism comprising a collage of units of 
Saxothuringian/Cadomian provenances, which are mixed with the Central Sudetic ophiolite.

Metagranitoids with $\sim 500 \mathrm{Ma}$ igneous emplacement ages (Oliver et al., 1993; Klimas, 2008, Mazur et al., 2010) occur also in the Strzelin Massif, in the East Sudetes. These rocks, known as the pale Stachów orthogneisses, are associated with metasedimentary rocks - the dark Stachów paragneisses. Both types of gneisses form the Stachów Complex which was thrust on the Strzelin Complex of the Brunovistulicum Terrane during the Variscan Orogeny (Oberc-Dziedzic and Madej, 2002; Oberc-Dziedzic et al., 2005a).

The aim of this contribution is to establish the provenance of the Stachów Complex rocks and assess their affinity to the Saxothuringian Terrane. We provide new SHRIMP (Sensitive High-Resolution lon Microprobe) U-Pb data for zircons from two samples of dark Stachów paragneisses and two samples of pale Stachów orthogneisses, and compare the results with published data for orthogneisses of similar age and their accompanying metasedimentary rocks from the Karkonosze-Izera Massif and the Orlica-Śnieżnik Dome, and for the Lusatian greywackes. In order to support similarity of metasedimentary rocks associating the $\sim 500$ Ma orthogneisses, we briefly characterize their lithology, and discuss their spatial relationships with the $\sim 500 \mathrm{Ma}$ orthogneisses. Finally, the unpublished (Madej, 2010) trace element and new Nd isotope signature of the dark Stachów gneisses is compared with published data for the mica schists associated with the $\sim 500 \mathrm{Ma}$ orthogneisses in the Karkonosze-Izera Massif and the Orlica-Śnieżnik Dome. Similar comparison for the $\sim 500 \mathrm{Ma}$ gneisses, including the pale Stachów orthogneisses, was previously published by Pin et al. (2007).

\section{GEOLOGICAL SETTING}

The Sudetes constitute the NE termination of the Bohemian Massif (Fig. 1A, B). The Sudetic Marginal Fault divides them into the mountainous Sudetic Block and the largely peneplained Fore-Sudetic Block (Fig. 1C).

The Strzelin Massif is situated $\sim 40 \mathrm{~km}$ south of Wrocław in the eastern part of the Fore-Sudetic Block. It crops out in two $\mathrm{N}-\mathrm{S}$-trending belts in the Lipowe Hills on the west and the Strzelin Hills on the east. On the west, the Strzelin Massif is juxtaposed along the Mała Ślęża Fault with the Kamieniec Ząbkowicki Belt (Fig. 2). The Kamieniec Ząbkowicki Belt is interpreted to belong either to the Saxothuringian Terrane (Franke and Żelaźniewicz, 2000; Chopin et al., 2012) or to the Moldanubian Terrane (Matte et al., 1990; Cymerman et al., 1997; Aleksandrowski and Mazur, 2002; Mazur et al., 2006).

The Strzelin Massif consists of two units separated by the Strzelin Thrust (Oberc-Dziedzic and Madej, 2002; Oberc-Dziedzic et al., 2005a) corresponding to the northern prolongation of the Moldanubian Thrust Zone (Suess, 1912) in the Fore-Sudetic Block. The footwall of the Strzelin Thrust is composed of the Strzelin Complex belonging to the Brunovistulicum, whereas the hanging wall of the thrust is made of the Stachów Complex (Fig. 3).

The Strzelin Complex (Fig. 3) comprises the Neoproterozoic gneisses, older schist series (composed of mica schists, calk-silicate rocks and amphibolites), and younger schist series made of the Jegłowa Beds which are correlated with the quartzite formation in the Jeseniki Mts of the East Sudetes (Bederke, 1931; Oberc, 1966), containing Early Devo- nian fossils (Chlupáč, 1975; Fig. 3). These rocks are exposed mainly in the Strzelin Hills.

The Stachów Complex rocks occur as large outcrops in the western part of the massif (Lipowe Hills), in two klippes situated north of Gościęcice and Strzelin in the northern part of the Strzelin Hills, and in a third small klippe south of Bożnowice (Fig. 3). Oberc (1972) regarded these klippes as remnants of the West Sudetic units thrust over the East Sudetic basement.

The Stachów Complex is composed of two contrasting types of gneisses: flaser orthogneisses, referred to as the pale Stachów gneisses, and fine-grained paragneisses, referred to as the dark Stachów gneisses. The latter are interlayered with mica schists, amphibole schists and rare amphibolites, and are interpreted to represent the metamorphic envelope of the granitoid protolith of the pale Stachów gneisses (Figs. 3 and $4 A)$. Both types of gneisses form the country rocks of the Variscan biotite granites exposed in the Strzelin quarries in which they also occur as xenoliths (Figs. 3 and 4B).

The dark Stachów gneisses (Fig. 4C, D) display three inter-layered varieties: (1) streaky gneiss without evidence of migmatization; (2) partly migmatized - banded, streaky gneisses, the most widespread variety of gneisses; (3) migmatic gneisses strongly folded (Madej, 2010). The banded, streaky gneisses contain intercalations of amphibolites and biotite-amphibole schists. The dark Stachów gneisses are fine-grained, dark grey, foliated rocks composed of quartz, plagioclase, K-feldspar, biotite, sillimanite, and rare muscovite.

The pale Stachów orthogneisses are known under different local names (Stachów gneiss, Gościęcice gneiss, Nieszkowice gneiss, Henryków gneiss) which were introduced before it was shown that all these gneisses belong to the same $\sim 500$ Ma generation and share similar petrographic and geochemical features (Oberc-Dziedzic et al., 2016 and references therein). The orthogneisses form sheets ranging from tens of centimetres up to $35 \mathrm{~m}$ in thickness, inter-layered with dark gneisses (Fig. 4A) or small bodies not accompanied by dark gneisses (the Gościęcice and Henryków gneisses). The pale Stachów gneisses show a sequence of textural varieties: rare, porphyritic, coarse-grained gneisses with poorly defined planar anisotropy, and more common augen, flaser, layered, and streaky gneisses. Augen and flaser gneisses often show pencil structures and stretching lineation (Fig. 4E). Augen 1-3 cm in size, are composed of variably deformed K-feldspar megacrysts or quartz-feldspar aggregates (Fig. 4F). In the Gościecice gneisses, nearly idiomorphic grey-blue microcline augen are rimmed by plagioclase. These augen are very similar to those occurring in the Izera granites and gneisses (Oberc-Dziedzic et al., $2005 b)$. The gneiss matrix is composed of quartz, plagioclase and biotite, usually forming monomineral domains.

\section{SAMPLING AND METHODS}

Four samples representative of typical gneisses of the Stachów Complex have been selected for SHRIMP zircon investigations, specifically, two dark Stachów gneisses (SA 1 and WL 5) and two pale Stachów orthogneisses (310C, 300V1).

The procedures used for zircon separation and isotope analysis with the Sensitive High-Resolution Ion Microprobe (SHRIMP II) were the same as those described by Oberc-Dziedzic and Kryza (2012) and are given in Appendix 1*.

The analytical results are listed in Appendices 2-5. Conventionally, the ages given in the text, if not otherwise stated, are 


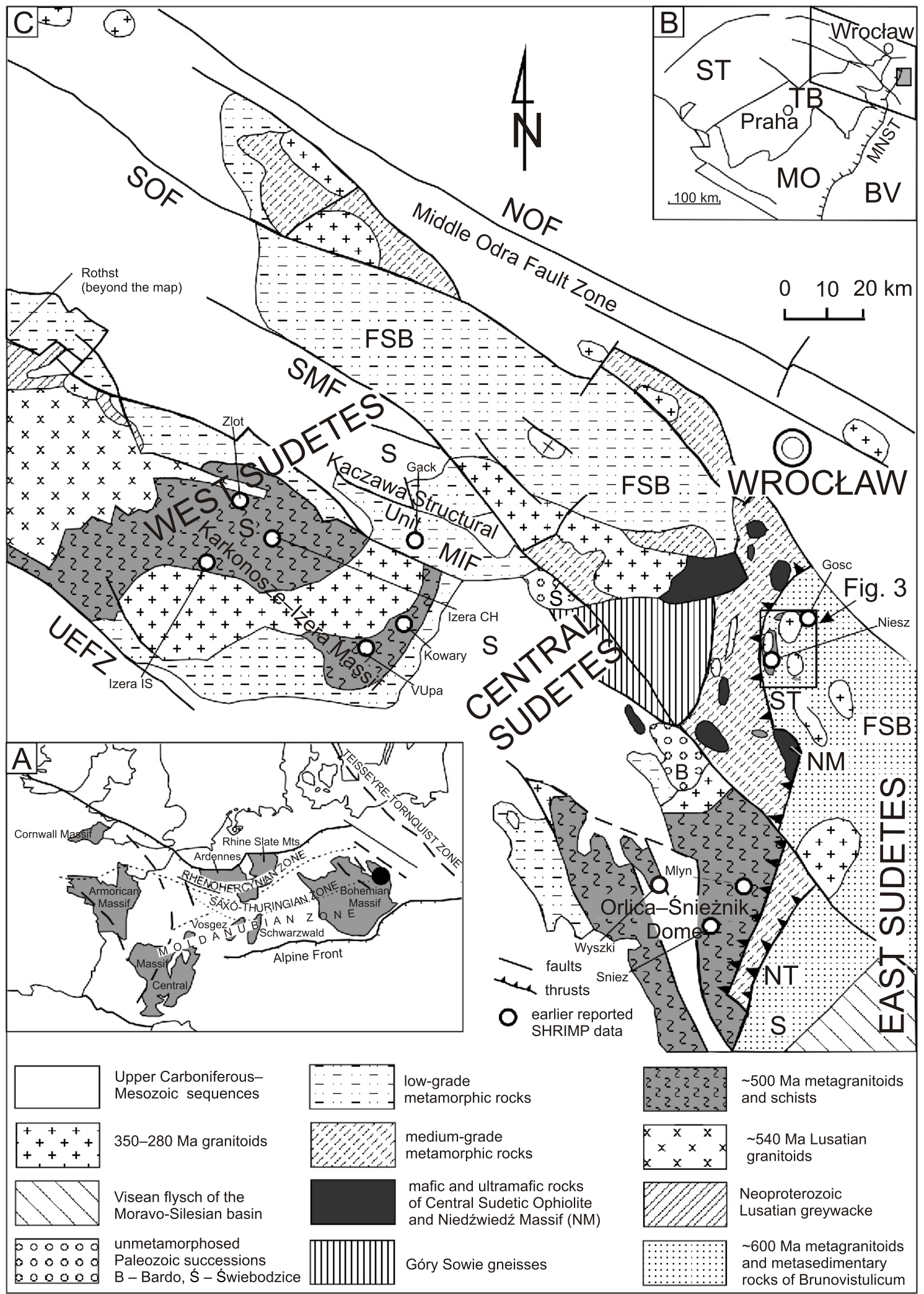

Fig. 1. Geological position of the Saxothuringian Terrane

A - location of the Sudetes (black dot) in the European Variscides; B - sketch map of the Bohemian Massif (MO - Moldanubian zones, ST Saxothuringian, TB - Teplá-Barrandian, after Franke, 2012) and Brunovistulicum (BV): MNST - Moldanubian-Nyznerov-Strzelin Thrust separating the Bohemian Massif from Brunovistulicum; quadrangle shows the location of the Sudetes; grey rectangle shows the position of the Strzelin Massif; C - sketch map of the Sudetes: B - Bardo Structural Unit, FSB - Fore-Sudetic Block, NM - Niedźwiedź Massif, S Sudetes; faults: MIF - Main Intra-Sudetic Fault, NOF - Northern Odra Fault, SMF - Sudetic Marginal Fault, SOF - Southern Odra Fault, UEFZ - Upper Elbe Fault Zone; thrusts: NT - Nyznerov Thrust, ST - Strzelin Thrust 


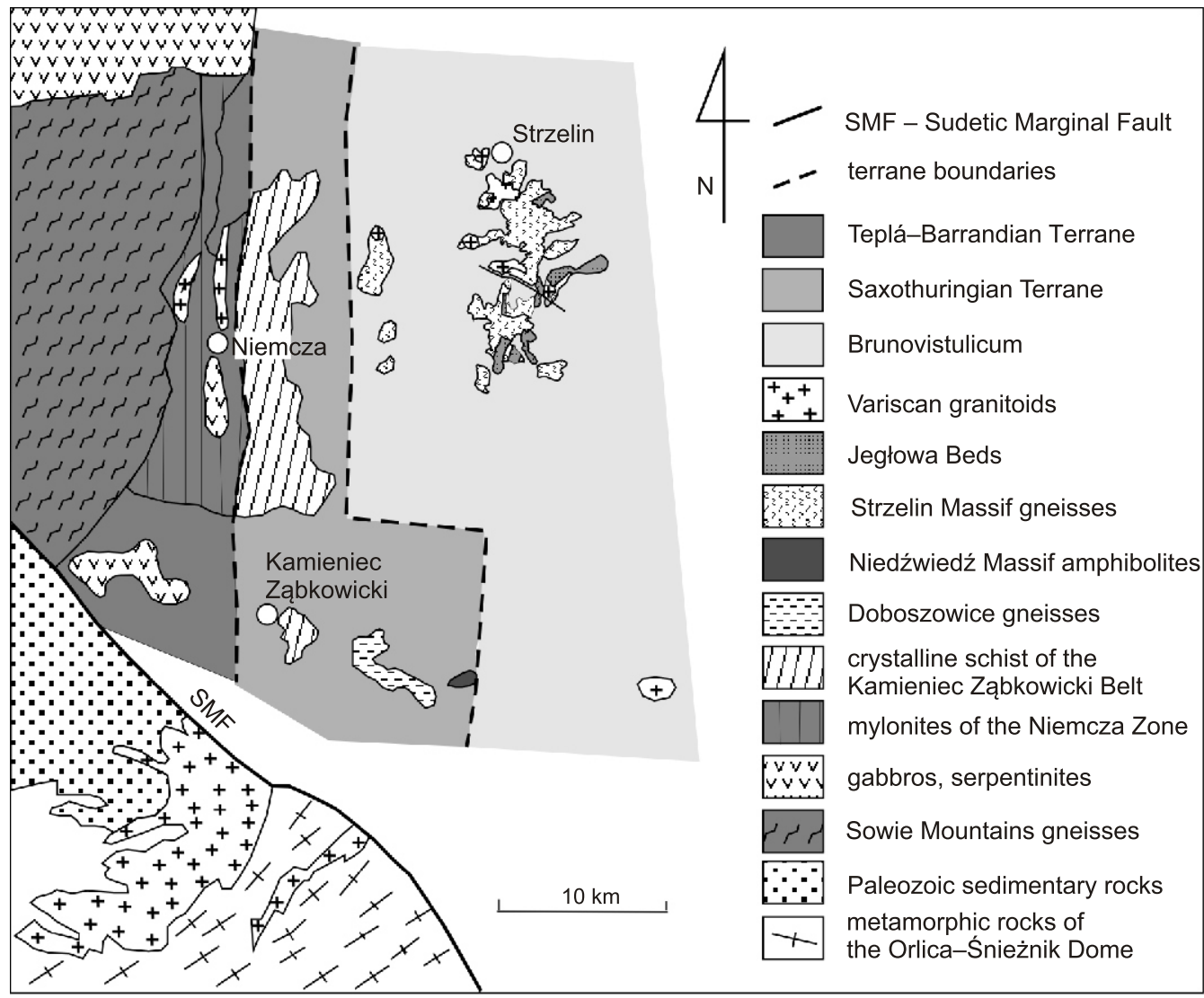

Fig. 2. Terranes in the eastern part of the Fore-Sudetic Block (modified from Franke, 2012)

${ }^{207} \mathrm{~Pb} /{ }^{206} \mathrm{~Pb}$ ages for zircons older than $650 \mathrm{Ma}$, and ${ }^{206} \mathrm{~Pb} /{ }^{238} \mathrm{U}$ ages for zircons younger than $650 \mathrm{Ma}$. The errors in the text and tables are given at the $1 \sigma$ level for individual points, and at the $2 \sigma$ level in Concordia diagrams and for average Concordia ages.

Two samples of dark Stachów gneisses have been analysed for Sm-Nd isotopes (Appendix 6), following procedures described in detail by Pin and Santos Zalduegui (1997) and summarized in Oberc-Dziedzic et al. (2016). The results are presented in Discussion.

\section{ZIRCON U-PB SHRIMP DATA}

\section{DARK STACHÓW GNEISS}

Sample SA 1 comes from the SA 1 borehole (depth 102.0; Fig. 4C), located in Sadowice, in the Lipowe Hills (Fig. 3). It is a dark to pale grey, fine-grained, well-foliated rock. The lighter parts of the gneiss contain rare leucocratic veins, $1-3 \mathrm{~mm}$ thick, in places swollen up to $10 \mathrm{~mm}$, and white spots, $1-2 \mathrm{~mm}$ across. The darker parts of gneiss are composed of plagioclase $\left(A n_{24-18}\right)$, biotite, sporadic muscovite and small $(0.6 \times 5 \mathrm{~mm})$ nodules of sillimanite (Sil, Fig. 5A). The lighter parts are a little coarser-grained and contain microcline. The white spots $(\mathrm{N}$, Fig. 5A) are composed of K-feldspar containing rounded, drop-like inclusions of plagioclase and quartz, and small biotite flakes aligned parallel or oblique to the foliation. These domains are interpreted as small leucosome pools, rotated after crystallization. Leucocratic veins are composed of quartz, plagioclase, $\mathrm{K}$-feldspar with irregular domains rich in $\mathrm{Ba}$, and muscovite.
In sample SA 1, most of the zircons are subhedral to subrounded, short- to normal-prismatic ( 100-200 $\mu$ m long and 50-100 $\mu \mathrm{m}$ wide), clean and transparent. Some others are darker, subrounded or irregular in shape.

In the CL images, the zircons display various internal structures. Most of the euhedral crystals show oscillatory zoning of igneous style, but a few grains have distinct and often large CL-bright internal domains containing vacuoles and inclusions (Fig. 6A).

In this sample, 17 points have been measured in 12 zircon grains (Appendix 2). One of the points (8.1) is strongly discordant, with $\mathrm{a}^{207} \mathrm{~Pb} /{ }^{206} \mathrm{~Pb}$ age of $2018 \pm 17 \mathrm{Ma}$ providing minimum estimate for the crystallization of this zircon, which might be of the same age as point 8.2 at $\sim 2090 \mathrm{Ma}$. The other data in this sample have a low to moderate degree of discordance, ranging from -9 to $+7 \%$. The ${ }^{206} \mathrm{~Pb}_{\mathrm{c}}$ contents are low, $0.35 \%$ at most. The $U$ and Th concentrations display a fairly large range (U: 55 - 1294 ppm, Th: 35 - 729 ppm).

Four concordant points, mostly in core domains, yielded Archean and Paleoproterozoic ${ }^{207} \mathrm{~Pb} /{ }^{206} \mathrm{~Pb}$ ages: 7.1: $2883 \pm$ 20, 6.1: $2784 \pm 18,10.1: 2468 \pm 23,8.2: 2089 \pm 18 \mathrm{Ma}$ (Fig. 6A).

Five other ${ }^{206} \mathrm{~Pb} /{ }^{238} \mathrm{U}$ ages are scattered between 738 and $663 \mathrm{Ma}$, with a mean Concordia age of $697 \pm 18 \mathrm{Ma}$ (Fig. 7A). Seven other points are significantly younger, between 623 and $583 \mathrm{Ma}$, with a mean Concordia age at $602 \pm 8 \mathrm{Ma}$ (Fig. 7B).

Sample WL $\mathbf{5}$ was taken from the outcrop near Nieszkowice village in the Lipowe Hills (Figs. 3 and 4D). It is a grey rock, showing a fine-grained structure (grain of $0.25-0.5 \mathrm{~mm}$ in size) and no distinct macroscopic foliation. A poorly visible folded layering is defined by an increased proportion of biotite. Under the microscope, the rock shows parallel ar- 


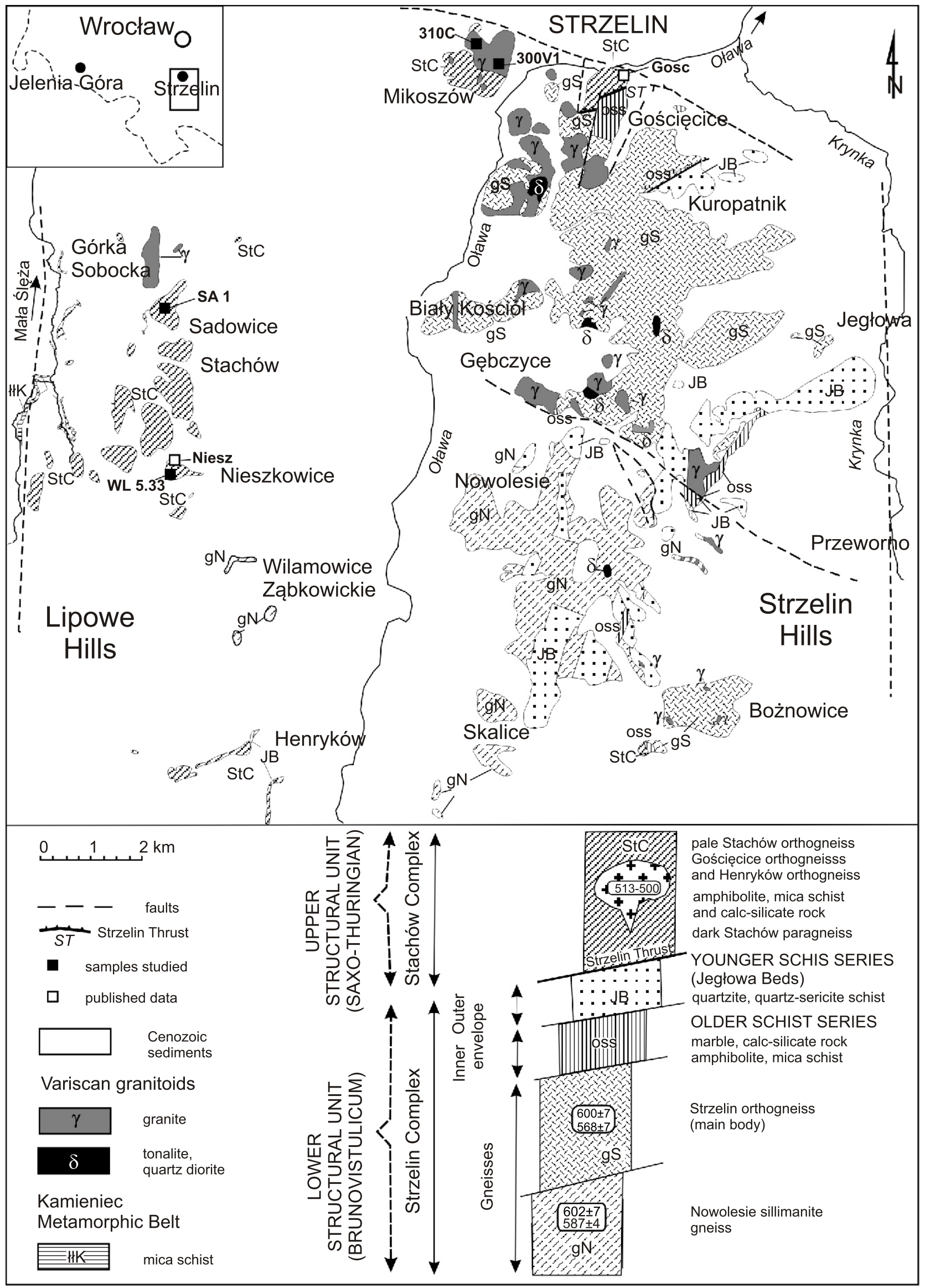

Fig. 3. Geological map of the Strzelin Massif (compiled by Oberc-Dziedzic and Madej, 2002; based on Wójcik, 1968; Wroński, 1973; Badura, 1979; Oberc et al., 1988) with location of samples analysed by SHRIMP method

Insert: Lower Silesia, simplified tectonic subdivision and lithology (excluding the Variscan granitoids) modified from Oberc-Dziedzic et al.

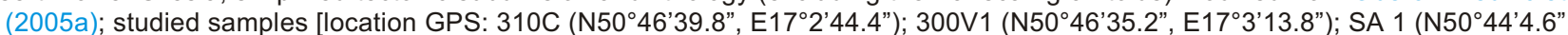

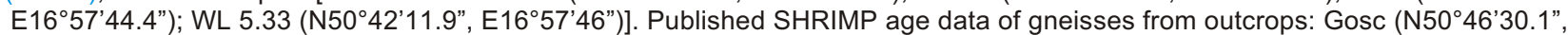
E17²'21.2"; Oliver et al., 1993; Mazur et al., 2010); Niesz (N5042'19.1”, E1658’3.9”; Klimas, 2008) 

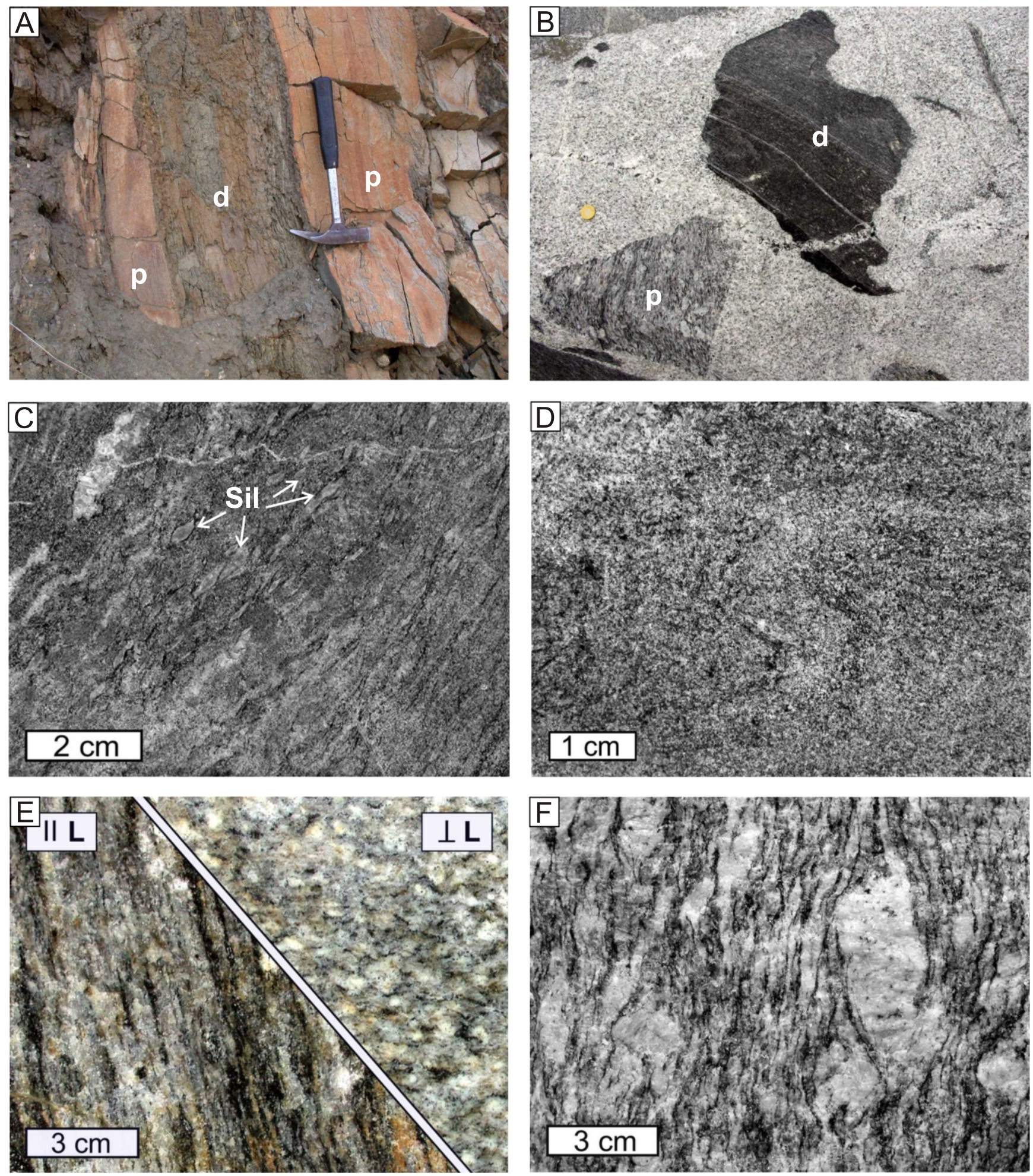

\section{Fig. 4. The Stachów gneisses}

A - sheets of the pale Stachów gneiss ( $p$ ) in the dark Stachów gneiss (d), foliation of both types of gneisses is uniformly oriented, the Mikoszów Quarry, NW wall, presently not existing; B - enclaves of the dark (d) and pale (p) Stachów gneisses in a medium-grained biotite granite block from the Strzelin I Quarry; C - dark Stachów gneiss, sample SA 1 from the SA 1 borehole (Sadowice, Lipowe Hills), sillimanite nodules (Sil) are visible; D - dark Stachów gneiss, sample WL 5; E - pale Stachów gneiss showing stretching lineation, sample 310C, taken from the right gneiss layer visible in photo A, Mikoszów Quarry; F - augen pale Stachów gneiss, sample 300V1 from an enclave in the medium-grained biotite granite, Strzelin I Quarry 

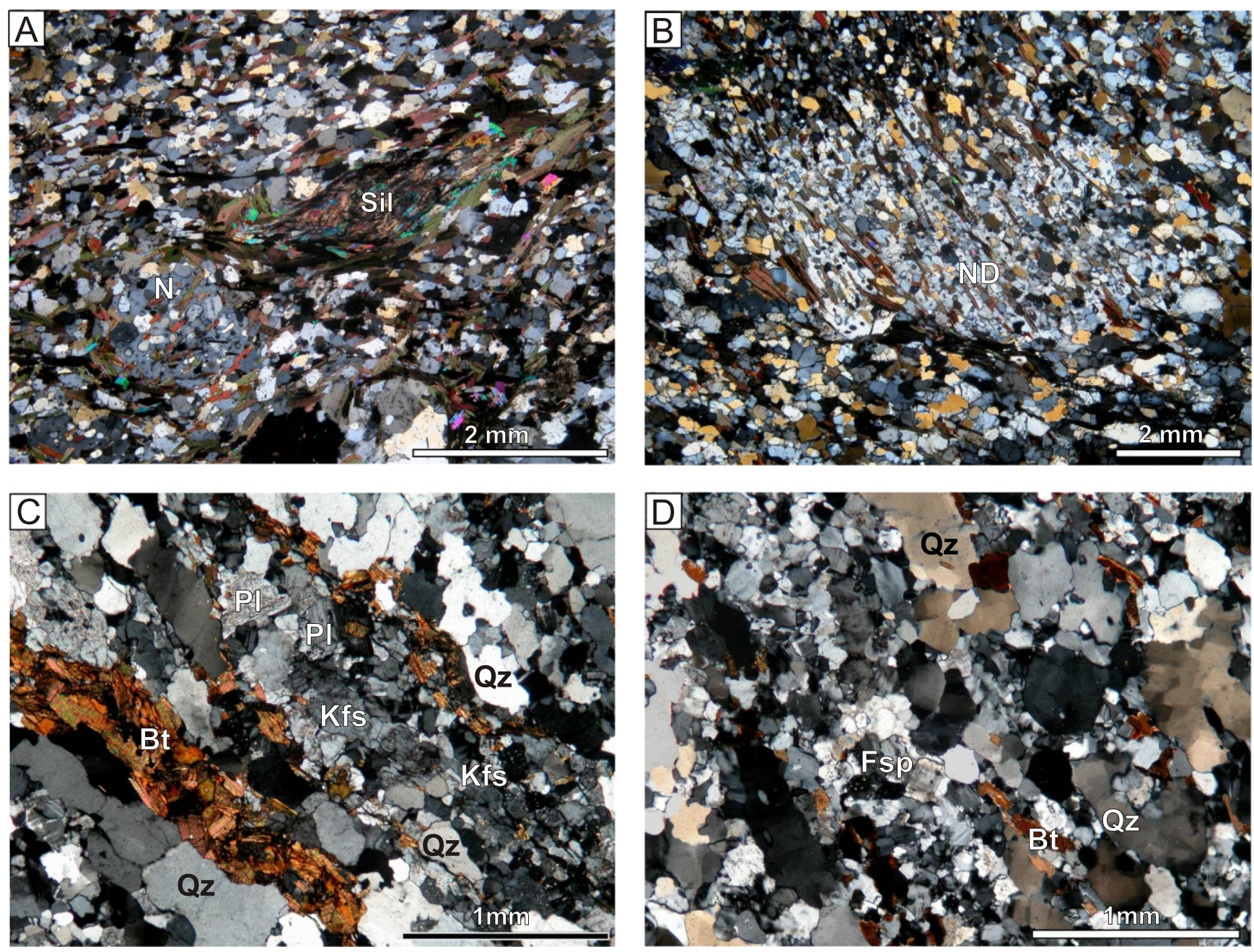

Fig. 5. Photomicrographs of the dark and pale Stachów gneisses selected for SHRIMP zircon investigations

A - dark Stachów gneiss, sample SA 1, nodule of muscovitized sillimanite (Sil) and white spot of neosome (N) are surrounded by quartz, biotite, plagioclase and rare microcline; B - dark Stachów gneiss, sample WL 5, domain of neosome (ND) composed of microcline with drop-like inclusions of quartz, plagioclase and parallel-aligned biotite flakes; $\mathbf{C}$ - pale Stachów gneiss, sample 310C, lenticular pod composed of quartz $(\mathrm{Qz})$, plagioclase $(\mathrm{PI})$ and microcline $(\mathrm{Kfs})$ is parallel to brown biotite strips (Bt) and quartz layers $(\mathrm{Qz})$; $\mathbf{D}$ - pale Stachów gneiss, sample 300V1, elongate quartz grains $(\mathrm{Qz})$, feldspars layer composed of plagioclase and microcline (Fsp), brown biotite plate (Bt); mineral abbreviations from Whitney and Evans (2010)

rangement of single biotite flakes embedded between quartz, plagioclase $\left(\mathrm{An}_{23-18}\right)$ and microcline grains (Fig. 5B). Rare, $3 \mathrm{~mm}$ long microcline grains contain sillimanite inclusions. Neosome domains form rounded white spots similar to those observed in sample SA 1, and several millimetre long domains (ND) composed of parallel-aligned grains of quartz, microcline with drop-like inclusions of quartz, plagioclase and flakes of biotite (Fig. 5B).

Most of the zircon grains are subrounded, rounded and subhedral, short- to normal-prismatic, 100-250 $\mu \mathrm{m}$ long and $80-150 \mu \mathrm{m}$ wide. The subhedral crystals are mostly clear, with a few inclusions. The rounded and subrounded grains are darker and have a mat surface.

In the CL images, the zircons reveal considerable variation of their internal structures. Many grains have CL-bright internal domains covered with darker oscillatory zoned overgrowths (e.g., grain 3.2). A number of subrounded crystals have CL-dark cores overgrown by CL-bright mantles and, locally, by CL-dark rims (e.g., grains 4 and 12). Quite many zircons are CL-dark, with some "ghost" zoning in the centre (e.g., 6.1; Fig. 6B).
Out of 24 analyses in 16 zircon grains (Appendix 3), one point (15.2) is highly discordant, while another one (7.1) shows a strong reverse discordance; these two analyses have been excluded from interpretation. The ${ }^{206} \mathrm{~Pb}_{\mathrm{c}}$ contents are between 0 and $0.47 \%$. The $U$ (50-1414 ppm) and Th (7-1283 ppm) concentrations are highly variable but mostly low to moderate. The ${ }^{232} \mathrm{Th} /{ }^{238} \mathrm{U}$ ratios are scattered between 0.03 and 3.1 , suggesting that some of the zircon domains analysed might have crystallized from metamorphic fluids (with low Th/U) rather than from silicate melts.

The ages are also very scattered. Three grains yield nearly concordant spots with Archean ${ }^{207} \mathrm{~Pb} /{ }^{206} \mathrm{~Pb}$ ages: 13.1: $2651 \pm$ $21,10.1: 2630 \pm 8$, and 1.1: $2605 \pm 12 \mathrm{Ma}$. Six other points have ${ }^{206} \mathrm{~Pb} /{ }^{238} \mathrm{U}$ ages within the range $1830-2200 \mathrm{Ma}$, but most of them are somewhat discordant, implying that their true ages might be close to the upper bound of that range. Two other analyses (2.1 and 8.1) give nearly concordant data points indicating an age of $\sim 1000 \mathrm{Ma}$.

The rest of the zircons (11 spots) yield ${ }^{206} \mathrm{~Pb} /{ }^{238} \mathrm{U}$ ages in the range of $570-630 \mathrm{Ma}$. Within this Late Neoproterozoic group, two subsets of ages might possibly be distinguished with 

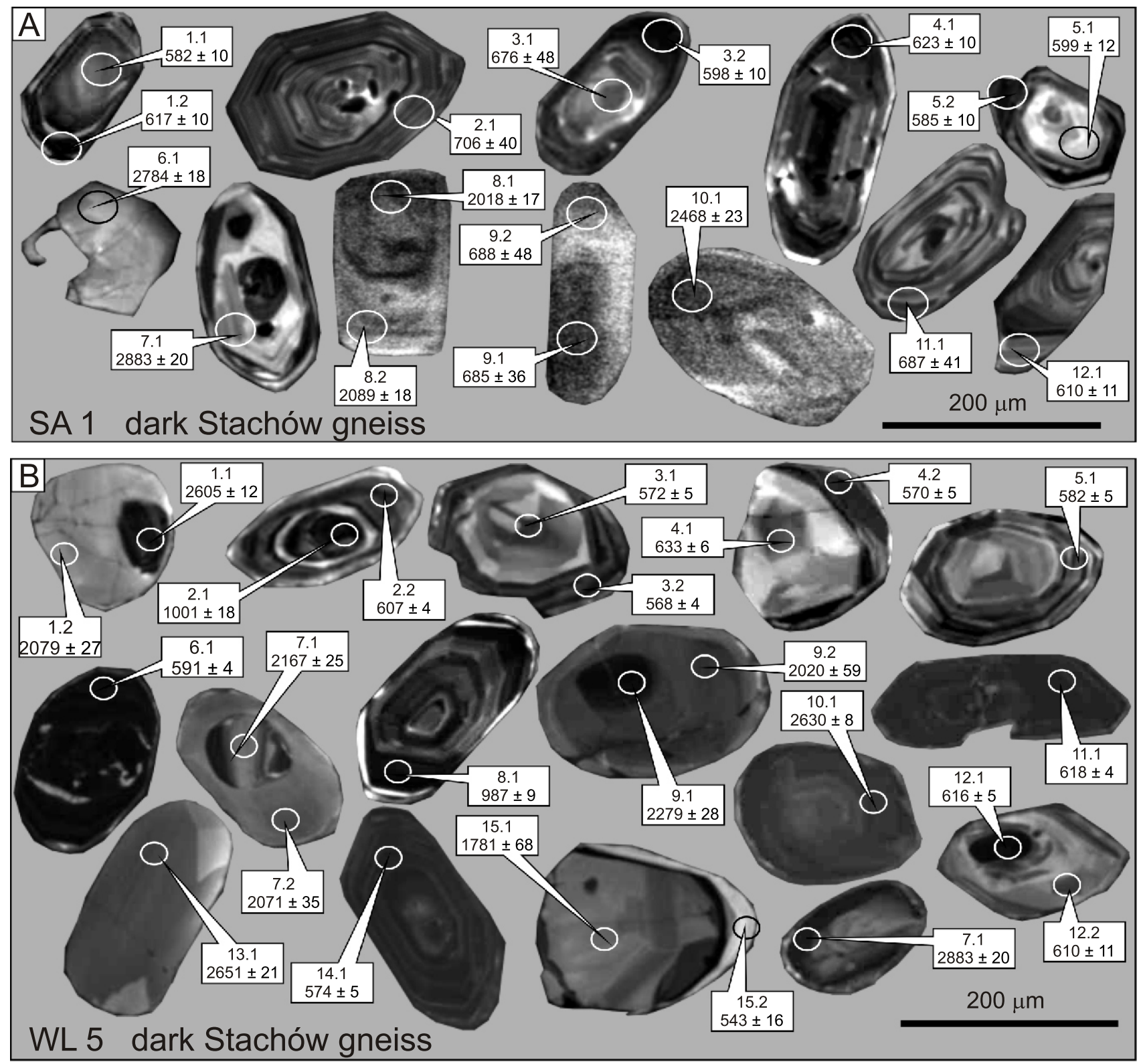

Fig. 6. CL images and ages of zircons from the dark Stachów gneisses

A - sample SA 1; B - sample WL 5

average Concordia ages of $617 \pm 4 \mathrm{Ma}$ (points $2.2,4.1,11.1$, 12.1, and 12.2; Fig. 7C) and $577 \pm 6 \mathrm{Ma}$ (points 3.1, 3.2, 4.2, 5.1, 6.1, and 14.1; Fig. 7D).

\section{PALE STACHÓW GNEISS}

Sample $310 \mathrm{C}$ was taken from the $50 \mathrm{~cm}$ thick packet in the dark gneisses exposed in the Mikoszów Quarry near Strzelin (Figs. 3 and 4A, E). It is a pale grey, yellowish, crudely layered gneiss composed of quartz-plagioclase-microcline lenticular pods with rare K-feldspar augen, up to $0.5 \mathrm{~mm}$ in diameter, and strips of brown biotite (Fig. 5C).

The zircon population in this sample is relatively homogeneous: normal-prismatic (up to $\sim 150 \mu \mathrm{m}$ long and $100 \mu \mathrm{m}$ wide), euhedral crystals prevail, with quite abundant "dusty" and oval inclusions. Darker rounded grains and broken crystals are also found.
In the CL images, the internal structure of the zircons appears rather complex. The internal domains are CL-darker or brighter, locally with irregular cloudy zoning. The external parts of the crystals are more regular, displaying oscillatory zonation (Fig. 8A).

In this sample, one point (6.2), out of 18 points analysed in 13 grains (Appendix 4), has been excluded from interpretation due to strongly reverse discordance. Common $\mathrm{Pb}$ is low, between 0 and $0.44 \%$, except in spot $13.1\left(1.6 \%{ }^{206} \mathrm{~Pb}_{\mathrm{c}}\right)$, causing the very large uncertainty of its ${ }^{207} \mathrm{~Pb} /{ }^{206} \mathrm{~Pb}$ age. The $U$ (222-829 ppm) and Th (16-532 ppm) concentrations are also uniform and moderate (except for point 10.1, with much higher contents). The ${ }^{232} \mathrm{Th} /{ }^{238} \mathrm{U}$ ratios are moderate to fairly high in most cases (mostly between 0.15 and 1.0), and suggestive of igneous crystallization.

With the exception of spot 1.1, which points to a minimum age of $\sim 620 \mathrm{Ma}$, the data points yield a spectrum of ages rang- 

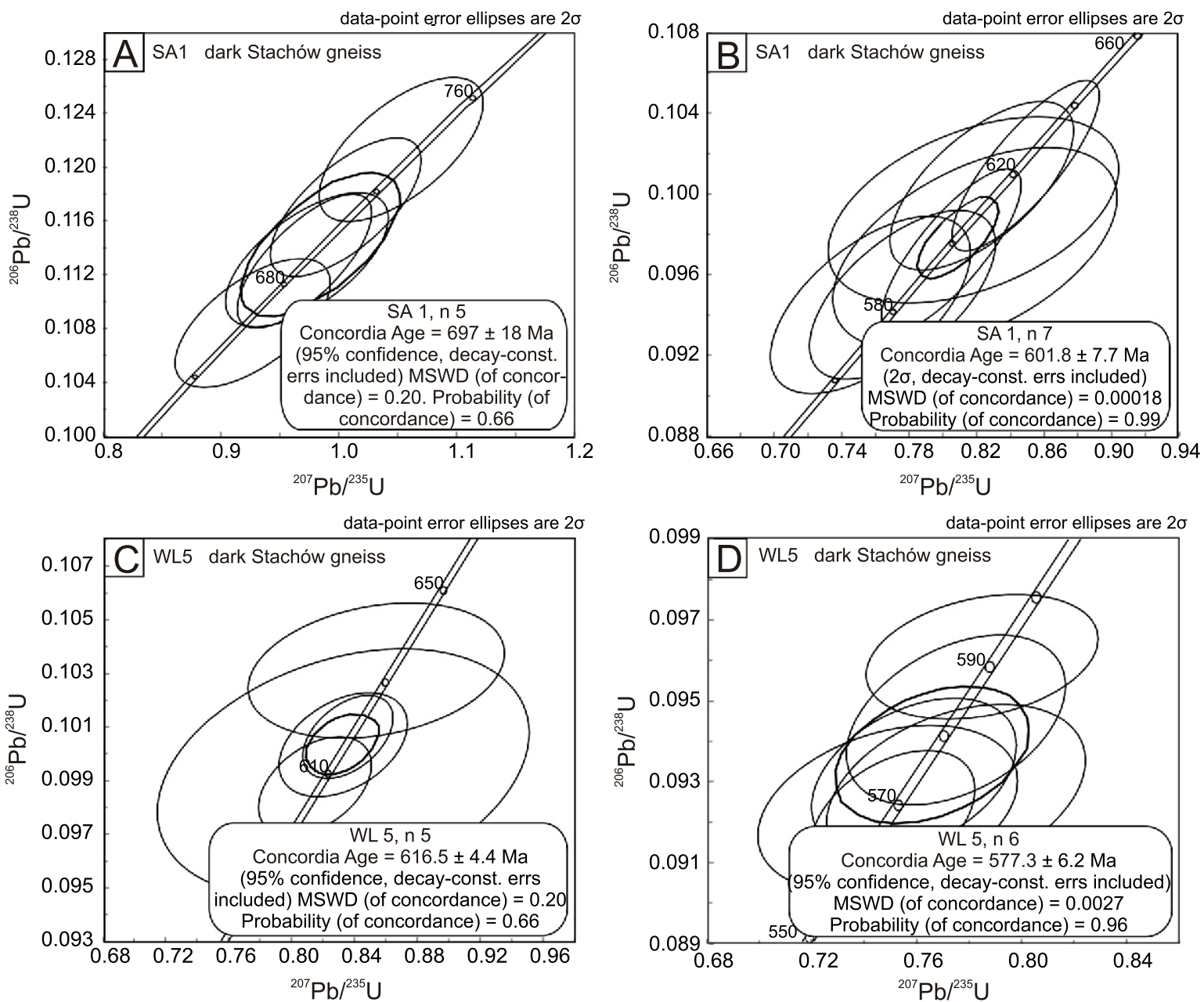

Fig. 7. Concordia diagrams for zircons from the dark Stachów gneiss

Sample SA 1: A - mean Concordia age of $697 \pm 18 \mathrm{Ma}$ for a group of 5 points between 738-663 Ma; B - mean Concordia age at $601.8 \pm 7.7 \mathrm{Ma}$ for group of 7 points between $\sim 583-623 \mathrm{Ma}$; sample WL 5 ; C - mean Concordia age of $616.5 \pm 4.4 \mathrm{Ma}$ for a group of 5 points between $605-635 \mathrm{Ma}$; D - mean Concordia age at $577.3 \pm 6.2$ Ma for group of 6 points between $\sim 559-597 \mathrm{Ma}$

ing from $450 \mathrm{Ma}$ to $580 \mathrm{Ma}$, within which three age groups may be defined with mean Concordia ages of $462 \pm 9 \mathrm{Ma}(n=3) ; 514$ $\pm 6 \mathrm{Ma}(\mathrm{n}=8$; Fig. 9A); $562 \pm 9 \mathrm{Ma}(\mathrm{n}=4$; Fig. 9B). The $514 \mathrm{Ma}$ group might possibly be further subdivided into two subgroups with average Concordia ages of $506 \pm 8 \mathrm{Ma}(\mathrm{n}=5)$ and $526 \pm$ $10 \mathrm{Ma}(\mathrm{n}=3)$. It is concluded that the $514 \pm 6 \mathrm{Ma}$ age calculated from the main group of zircons (8 spots) provides a reasonable estimate of the igneous emplacement age. The $\sim 560 \mathrm{Ma}$ and $\sim 460$ Ma dates measured on fewer grains are interpreted to reflect the age of an inherited component and the apparent, geologically meaningless, age of zircon domains which suffered radiogenic lead loss, respectively.

Sample $300 \mathrm{~V} 1$ was taken from a xenolith, $1.5 \mathrm{~m}$ in size, found in the medium-grained Strzelin granite of the Strzelin I Quarry (Fig. 3). It is a light-coloured grey rock composed of quartz, feldspars and biotite (Fig. 4F). Quartz domains comprise elongate grains up to $1 \mathrm{~mm}$. Feldspars form layers up to $5 \mathrm{~mm}$ thick, composed of plagioclase $\left(A n_{18}\right)$ and microcline $0.15-0.25 \mathrm{~mm}$ across. Microcline augen are rare. Biotite shows yellow-brown pleochroism and includes numerous zircon inclusions surrounded by pleochroic haloes (Fig. 5D).
The zircons are homogeneous in their habits and internal structure. They are euhedral to subhedral, normal-prismatic, $\sim 80-120 \mu \mathrm{m}$ long and 30-80 $\mu \mathrm{m}$ wide. Many crystals have irregular outlines and some are broken. Some grains display CL-dark interiors and moderately bright external parts (grains 2, 4, 8, 9 and 12), while a few show CL-brighter cores (1 and 17). Many grains exhibit distinct zonation, both in the inner and outer parts of the grains (Fig. 8B).

Twenty-one analyses have been made in 21 grains (Appendix 5). The ${ }^{206} \mathrm{~Pb}_{\mathrm{c}}$ contents are low, between 0 and $0.63 \%$ (except in point 8.1: 1.23\%). The $U$ and Th concentrations are also low to moderate, between 116-1563 ppm and 57-1287, respectively. The ${ }^{232} \mathrm{Th} /{ }^{238} \mathrm{U}$ ratios fall within the moderate range of 0.17-0.87.

Several analyses are reversely discordant and should be treated with caution.

Five concordant dates are older that the main age population of zircons and their ${ }^{206} \mathrm{~Pb} /{ }^{238} \mathrm{U}$ ages are at $\sim 617,560,528$ (two points) and $510 \mathrm{Ma}$ (Fig. 9C). The two grains with ages of $\sim 617$ and 560 Ma document the presence of zircons which might have been inherited from the magma source, or alterna- 

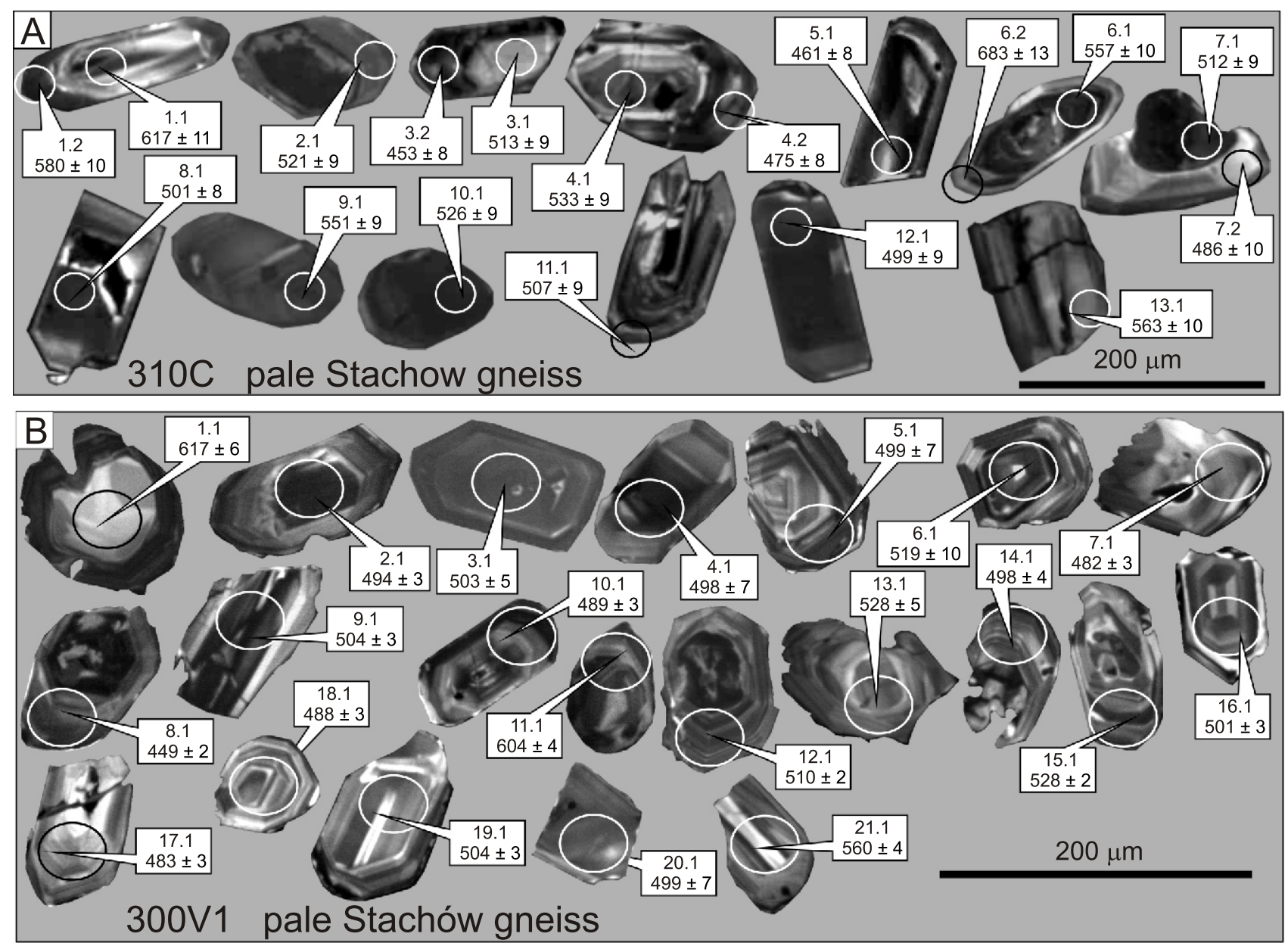

Fig. 8. CL images and ages of zircons from the pale Stachów gneisses

$$
\text { A - sample 310C; B - sample 300V1 }
$$

tively incorporated as xenocrysts in the magma at a later stage. The meaning of two grains with $528 \mathrm{Ma}{ }^{206} \mathrm{~Pb} /{ }^{238} \mathrm{U}$ apparent ages is dubious in view of their significant degree of discordance. The 510 Ma concordant grain 12.1 might have been included in the main group.

The main group of ${ }^{206} \mathrm{~Pb} /{ }^{238} \mathrm{U}$ dates comprising 11 points, is in the narrow range of 498-504 Ma. Excluding three relatively discordant points, the remaining 8 points yield a well-defined mean Concordia age of $499 \pm 4 \mathrm{Ma}$ (Fig. 9D) interpreted as reflecting the emplacement age of the igneous protolith. Two grains are somewhat younger, at $\sim 483 \mathrm{Ma}$, probably reflecting radiogenic lead loss.

\section{DISCUSSION}

Based on our new age data for the dark and pale Stachów gneisses, we compare these gneisses with the $\sim 500 \mathrm{Ma}$ orthogneisses and associated metasedimentary rocks occurring out of the Strzelin Massif, in the Sudetic part of the Saxothuringian Terrane.

COMPARISON OF THE ZIRCON AGE SPECTRA OF THE STACHÓW GNEISSES AND SELECTED ROCKS OF THE SAXOTHURINGIAN TERRANE

Dark Stachów gneisses. The heterogeneous zircon population, including many rounded, subrounded and subhedral grains, and the wide scatter of their U-Pb ages provide strong evidence for a sedimentary derivation of their protolith. Specifically, the new SHRIMP zircon age data for samples SA 1 and WL 5 display similarities, but also some differences (Fig. 10A, $B)$. In both samples, the main ages broadly cluster in the same -570-630 Ma range, implying a younger depositional age. However, sample SA 1 has an additional significant population at $\sim 660-690 \mathrm{Ma}$ (Fig. 11A, B). There are also some differences in the distribution of older recycled components, although the relatively low number of dated zircons puts strong limitations on the inferences which can be drawn from our data. However, in both samples, the following individual dates are present: 2100-2200 Ma, 2400-2500 Ma, 2700-2800 Ma. Interestingly, two grains in WL 5 point to a $\sim 1000$ Ma old component, which would deserve confirmation by further analyses on a larger zircon population (Appendices 2 and 3).

The two newly analysed samples of the Stachów dark gneisses have been compared with earlier reported SHRIMP data from six samples of selected metapelites and metagreywackes of Lusatia along with paragneisses and mica schists accompanying the $\sim 500 \mathrm{Ma}$ orthogneisses in the Karkonosze-Izera Massif and Orlica-Śnieżnik Dome (Figs. $10 \mathrm{C}-\mathrm{H}$ and $11 \mathrm{C}-\mathrm{H}$ ). In all the samples the main zircon populations are represented by broadly "continuous" spectra within the range of $\sim 550-660 \mathrm{Ma}$, and scarce, but symptomatic individual points between $\sim 700$ and $800 \mathrm{Ma}$ (Fig. 11C-H).

In spite of this distinct similarity, the samples show some differences. In the Rothstein Fm. (meta)greywacke (Rothst) 

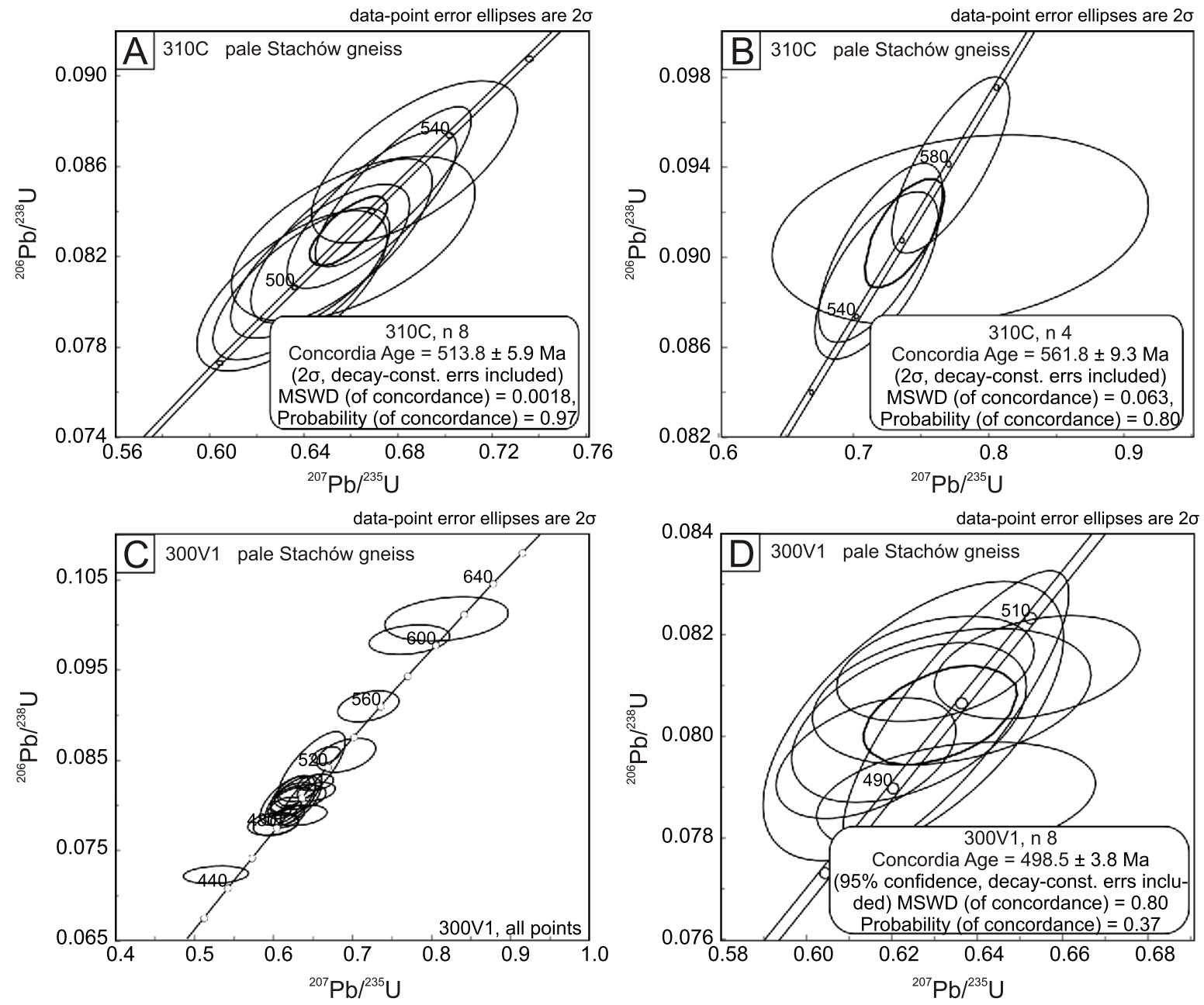

Fig. 9. Concordia diagrams for zircons from the pale Stachów gneiss

Sample 310C: A - mean Concordia age of $513.8 \pm 5.9$ Ma for a group of 8 points; B - mean Concordia age of $561.8 \pm$ 9.3 Ma for a group of 4 points; sample 300V1; C - Concordia diagram for all points; D - mean Concordia age of $498.5 \pm$ 3.8 Ma for a group of 8 points

(Linnemann et al., 2007), the Złotniki Lubańskie mica schist (Zlot; Żelaźniewicz et al., 2009), and the Wyszki paragneiss (Wyszki; Mazur et al., 2015), just as in the dark Stachów gneiss (SA 1, WL 5), zircon grains younger than 550 Ma were not found.

In the Młynowiec paragneiss (sample Mlyn), five of the total of 44 analyses, fall between 515 and $547 \mathrm{Ma}$ (Jastrzębski et al., 2010), thus extending the younger shoulder of the main age population. On the other hand, in the same formation, Mazur et al. (2012) reported only one analysis with an age of $548 \mathrm{Ma}$. The significance of this observation is unclear because the younger dates could merely reflect radiogenic lead loss not resolved by in situ U-Pb analyses. Indeed, Mazur et al. (2012) interpreted their $548 \mathrm{Ma}$ date as a result of $\mathrm{Pb}$-loss either by continuous diffusion or episodic response to later metamorphism, but Jastrzębski et al. (2010) interpreted only one result at $\sim 515 \mathrm{Ma}$ as reflecting lead loss, and considered 10 ages between 561 and $531 \mathrm{Ma}$ as concordant.

Somewhat younger zircons were found in the Stronie mica schist (Fig. 11H), i.e. 13 analyses in the 550-466 Ma time span, with only 4 ages younger than $500 \mathrm{Ma}$ (Jastrzębski et al., 2010).

In contrast to the rest of the samples studied, the VUpa sample VU371 (a quartzite from the lowermost part of the mica schist complex from the lower thrust sheet) shows, besides
550-670 Ma old zircons, a large proportion of younger zircons with ages as young as $\sim 446 \mathrm{Ma}$ (Fig. 11D) and nearly half of the grains measured falling within the range 446-550 Ma (Žačkova et al., 2012). Zircon grains of similar age were reported from quartzofeldspathic metavolcanogenic rocks of the mica schist series in the eastern part of the Karkonosze-Izera Massif (Oberc-Dziedzic et al., 2010).

Zircons of Ediacaran age predominate in all the rocks compared with the dark Stachów gneisses, except in the VUpa quartzite and the Stronie mica schist, which also contain younger, Cambrian to Late Ordovician zircons. In low- to medium-grade metamorphic rocks, they may be used to put constraints on the ages of the source materials and to approximate the oldest possible deposition age of their sedimentary protoliths.

Besides these Late Neoproterozoic or Early Paleozoic components, much older Precambrian zircons are also frequent, but their age distributions display some differences from sample to sample. Four of the six samples compared have practically no dates within the 1000-1800 Ma range, which is considered as symptomatic of the Armorican crust (Friedl et al., 2000), whereas in two others (VUpa and Mlyn), such zircons are present but scarce ( 4 and 5 grains, respectively, out of the total 44 and 59 points measured). Characteristically, all the samples 

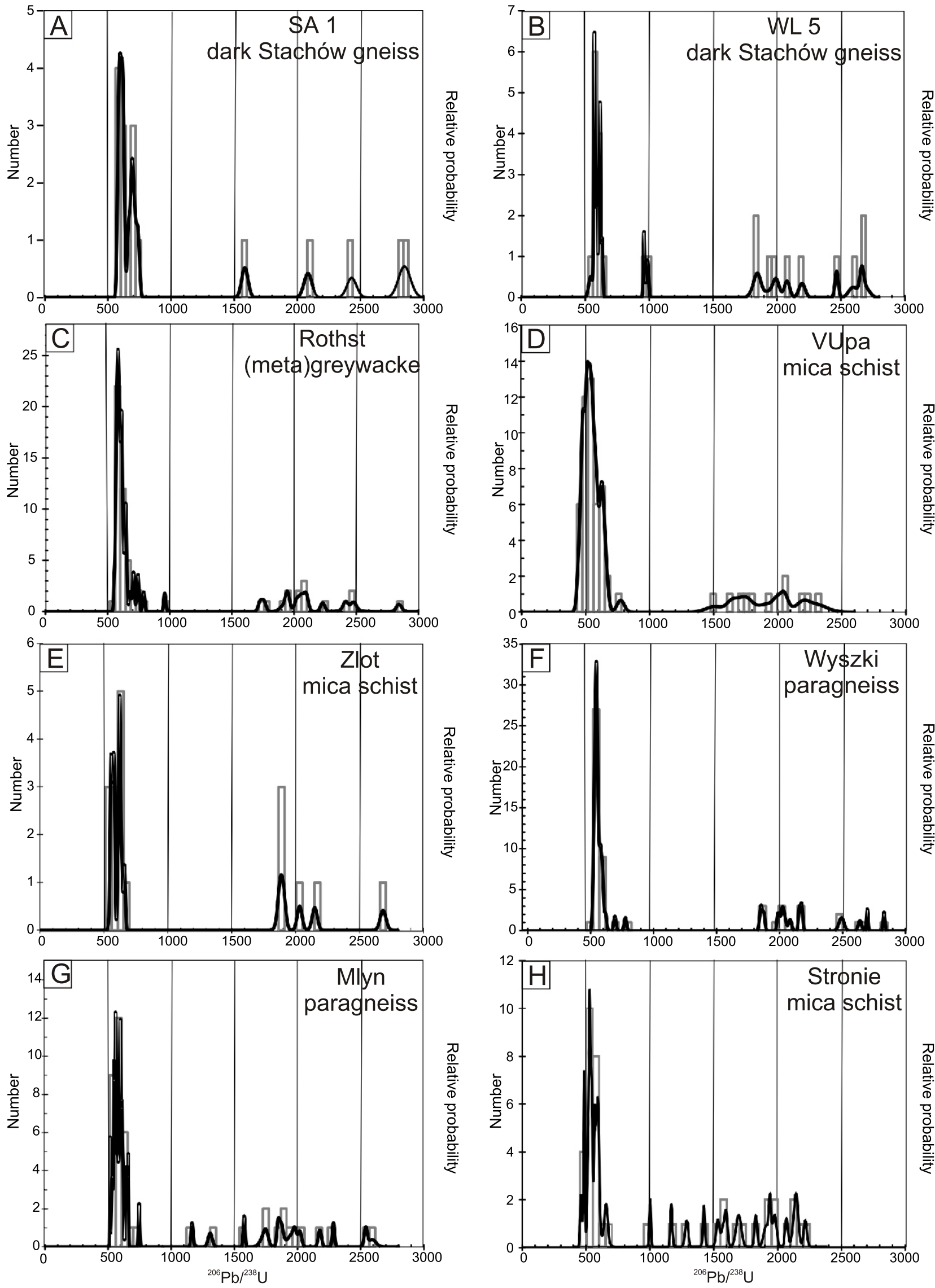

Fig. 10. Distribution of detrital zircon ages from the Neoproterozoic dark Stachów gneisses compared with zircon ages from Lusatian greywacke and metasediments of the Karkonosze-Izera Massif and Orlica-Śnieżnik Dome, presented as a histogram (group of rectangles) and a cumulative probability plot (black curved line)

Strzelin Massif, dark Stachów gneiss, this study: A - SA 1; B - WL 5; Lusatian Massif: C - Rothst - (meta)greywacke, Ediacaran, Rothstein Fm., Torgau-Doberlug Syncline (Linnemenn et al., 2007); Karkonosze-Izera Massif: D - VUpa - mica schist, S Karkonosze, lower thrust sheet (Žačkova et al., 2012); E - Zlot - mica schist, Złotniki Schist Belt (Żelaźniewicz et al., 2009); Orlica-Śnieżnik Dome: F - Wyszki Wyszki paragneiss, Młynowiec Formation (Mazur et al., 2015); G - Mlyn - Młynowiec paragneiss, Młynowiec Formation (Jastrzębski et al., 2010); H - Stronie mica schists, Stronie Formation (Jastrzębski et al., 2010) 

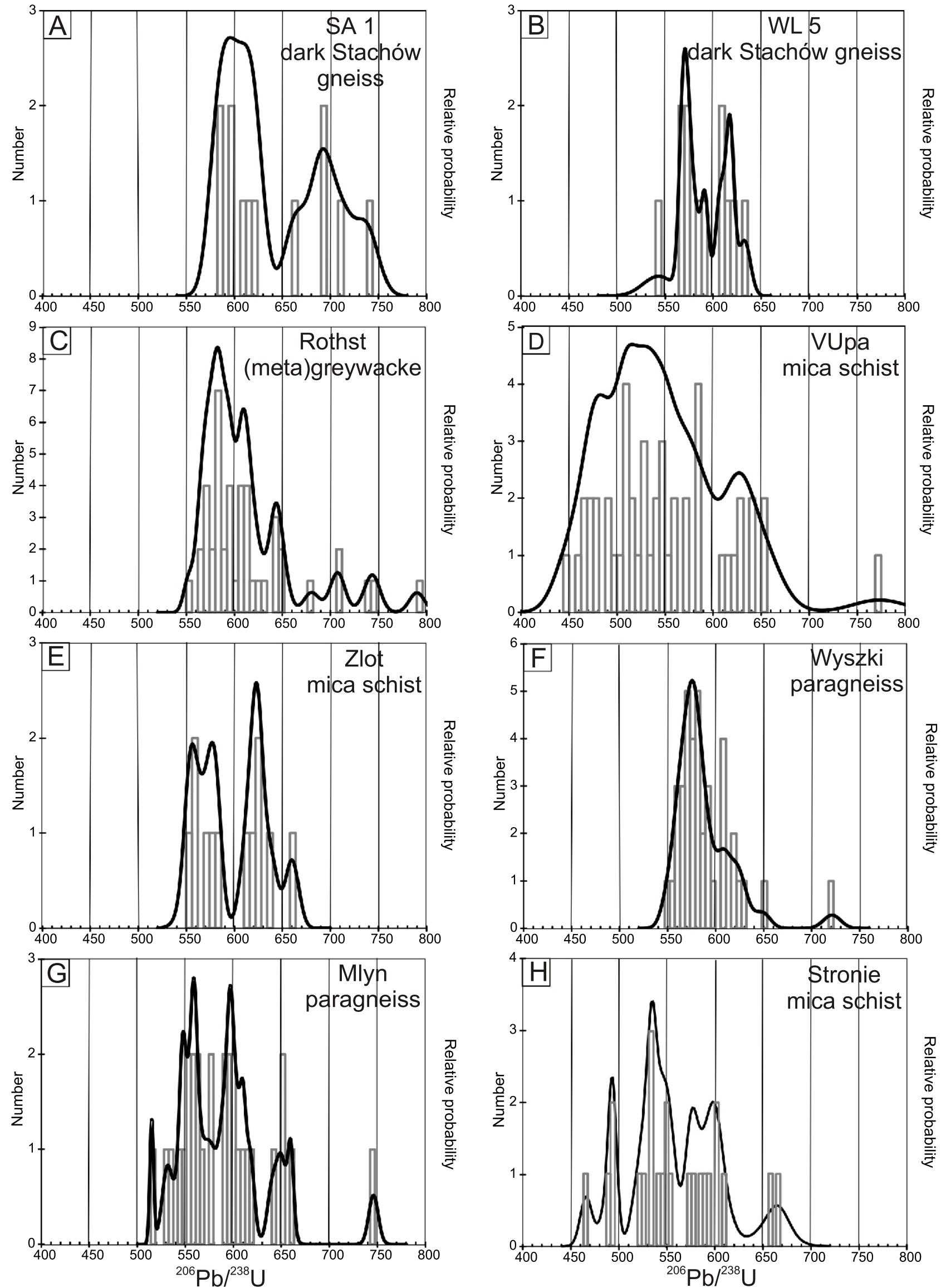

Fig. 11. Distribution of detrital zircon ages < 800 Ma from the Neoproterozoic dark Stachów gneisses compared with zircon ages from Lusatian greywacke and metasediments of the Karkonosze-Izera Massif and Orlica-Śnieżnik Dome, presented as a histogram (group of rectangles) and a cumulative probability plot (black curved line) 
have ages patterns with peaks at $\sim 1900-2200 \mathrm{Ma}$, and a few of them also display older grains in the 2400-2800 Ma range.

Pale Stachów orthogneisses. The homogeneity and morphology of the zircons from $310 \mathrm{C}$ and $300 \mathrm{~V} 1$ samples suggest that most of them crystallized from a granitic melt. Indeed, age data (Fig. 9) reveal only a small component of older Precambrian zircons, exemplified by grains with minimum ages of $\sim 680 \mathrm{Ma}$ in sample $310 \mathrm{C}$. The ${ }^{206} \mathrm{~Pb} /{ }^{238} \mathrm{U}$ ages are scattered between $\sim 562 \mathrm{Ma}$ and $462 \mathrm{Ma}$, with an $\sim 514 \mathrm{Ma}$ dominant age in sample 310C, and between $617 \mathrm{Ma}$ and $483 \mathrm{Ma}$, with a distinct main age group at $499 \pm 4 \mathrm{Ma}$ in sample $300 \mathrm{~V} 1$. The large scatter probably reflects the combination of various degrees of zircon inheritance (recycled grains, much older than $\sim 500 \mathrm{Ma}$, irrespective of their precise origin) and radiogenic $\mathrm{Pb}$-loss (ages younger than $\sim 500 \mathrm{Ma}$ ), producing strings of data points close to the Concordia curve which SHRIMP cannot resolve from truly concordant data due to the large counting statistics uncertainty of the low abundance of ${ }^{207} \mathrm{~Pb}$ (e.g., Pin and Rodriguez, 2009). Keeping in mind this basic methodological limitation, the alternative hypothesis that these ages reflect several magmatic/anatectic pulses is believed to be less plausible, or at least cannot be supported by the available data. In brief, it is conservatively concluded that a precise assessment of the true igneous emplacement age(s) within the $\sim 490-520$ Ma time span cannot be reached based on our data. In spite of this, it is clear that the igneous protoliths of the Stachów orthogneisses share the same $\sim 500 \mathrm{Ma}$ igneous emplacement age as orthogneisses widespread in the West and Central Sudetes.

The new SHRIMP zircon age data for the two samples of the pale Stachów gneisses, 310C and 300V1, have been compared with earlier reported SHRIMP data of the pale Stachów gneisses from the Strzelin Massif: Gosc (Mazur et al., 2010) and Niesz (Klimas, 2008); and with additional 500 Ma gneisses from the other parts of the Sudetes (Fig. 3): Sniez - Śnieżnik gneiss from the Śnieżnik Massif (Turniak et al., 2000) and three gneiss samples from the Karkonosze-Izera Massif: Izera $\mathrm{CH}$ (Oberc-Dziedzic et al., 2009), Izera IS (Żelaźniewicz et al., 2009) and Kowary (Oberc-Dziedzic et al., 2010). It is worth noting that results obtained by Turniak et al. (2000) for the Śnieżnik gneisses have been recently confirmed by Redlińska-Marczyńska et al. (2016).

The main zircon age ranges, between 300 and $800 \mathrm{Ma}$, in the samples compared are shown in Figure 12. For simplicity, the ${ }^{206} \mathrm{~Pb} /{ }^{238} \mathrm{U}$ ages of all data points have been plotted. Even older inherited grains, which are usually scarce, are discussed below.

In general, the main age peak in all the samples is between $\sim 480$ and $520 \mathrm{Ma}$, with the maximum close to $500 \mathrm{Ma}$ (only in the Kowary gneiss the maximum is at $\sim 480 \mathrm{Ma}$ ). A few dates are significantly younger, within the range of $420-480 \mathrm{Ma}$, and only in the Śnieżnik gneiss, two much younger ages of $\sim 327$ and $336 \mathrm{Ma}$ have been found and interpreted as a record of Visean metamorphism (Turniak et al., 2000).

Zircon ages older than $800 \mathrm{Ma}$ are also scarce $\left({ }^{207} \mathrm{~Pb} /{ }^{206} \mathrm{~Pb}\right.$ ages with $1 \sigma$ uncertainty, unless specified otherwise): Gosc: $715 \pm 190$ (D 41), $1640 \pm 41$ (D 96), $1767 \pm 8$ (D 23), $1828 \pm 51$ (D 34), $2912 \pm 11 \mathrm{Ma}$ (D 16); Niesz: $1916 \pm 25 \mathrm{Ma}\left({ }^{206} \mathrm{~Pb} /{ }^{238} \mathrm{U}\right.$ age); Sniez: $2616 \pm 59 \mathrm{Ma}\left({ }^{206} \mathrm{~Pb} /{ }^{23} \mathrm{U}\right.$ age); Izera $\mathrm{CH}: 983 \pm$ 226 (D 50), $1953 \pm 23$ (D -11), $3368 \pm 9 \mathrm{Ma}\left(\mathrm{D}-2,{ }^{207} \mathrm{~Pb} /{ }^{206} \mathrm{~Pb}\right.$ age); Izera IS: $2116 \pm 14 \mathrm{Ma}$ (D -6); Kowary: $1955 \pm 17 \mathrm{Ma}$ (D 24). The $3368 \pm 9 \mathrm{Ma}$ zircon date from Izera $\mathrm{CH}$ is similar to the $3417 \pm 8 \mathrm{Ma}$ date $\left({ }^{207} \mathrm{~Pb} /{ }^{206} \mathrm{~Pb}\right.$ age $)$ reported by Kryza et al. (2007) from the Gackowa sandstone (Kaczawa Belt). These are the oldest zircons documented in the Sudetes so far.

Summing up, all the pale Stachów gneiss samples (310C, 300V1, Gosc and Niesz) have very similar zircon age spectra, with a prominent peak at $\sim 500 \mathrm{Ma}$, and subordinate dates between $\sim 420-480$ and 530-620 Ma. The older dates are scarce (except for sample Gosc where, however, the old ages are mostly discordant). These age spectra are also very similar to the zircon dates reported from other orthogneisses of the Sudetes, i.e. the Izera, Kowary and Śnieżnik gneisses. Among the old inherited zircon dates, a distinct group is at 1950-2200 Ma. However, in general, there is a distinct gap between 1000-1800 Ma, which is typical of materials ultimately derived from the West African craton and, in Europe, the crust of the Armorica Terrane (Friedl et al., 2000).

The zircon age data support the view that orthogneisses of the Stachów Complex belong to the $\sim 500 \mathrm{Ma}$ group of orthogneisses, common in the Saxothuringian Zone (Pin et al., 2007). Moreover, the ages of the inherited zircons suggest that the sources for their granitic precursors were similar to those found in Armorica.

The age patterns of detrital zircons of the dark Stachów paragneisses display features similar to those from the Lusatian greywacke, Złotniki Lubańskie mica schists and Wyszki and Młynowiec paragneisses, all considered as belonging to the Saxothuringian Terrane (Linnemann et al., 2004, 2007; Szczepański and IInicki, 2014; Mazur et al., 2015). The age similarity of the dark Stachów gneisses and other metasedimentary rocks accompanying the $\sim 500 \mathrm{Ma}$ orthogneisses, suggests that they also belong to the Saxothuringian Terrane.

COMPARISON OF THE CHARACTERISTIC FEATURES OF THE 500 MA ORTHOGNEISSES AND ACCOMPANYING METASEDIMENTARY ROCKS

The Stachów, Izera and Śnieżnik orthogneisses are accompanied by metasedimentary rocks, namely: the dark Stachów gneisses, mica schists of the Złotniki Lubańskie, Stara Kamienica and Szklarska Poręba Belts, and rocks of the Młynowiec and Stronie formations, respectively. These rocks differ not only as to their mineral composition which reflects the nature of their protholith and the degree of metamorphism, but also by their associated rocks. The dark Stachów gneisses (1: Oberc-Dziedzic, 1995; Madej, 2010), the Złotniki Lubańskie mica schists (2: Żelaźniewicz et al., 2009) and paragneisses of the Młynowiec Formation (3: Jastrzębski et al., 2010) all form monotonous series with small admixtures of volcanogenic material. In contrast, the mica schists of the Stara Kamienica Belt in the Karkonosze-Izera Massif are accompanied by quartzites, leptynites, calc-silicate rocks and amphibolites (Kozłowski, 1974), whereas the Stronie Formation in the Orlica-Śnieżnik Dome is composed of mica schists with interlayers of light-coloured or graphitic quartzites, amphibolites, marbles and leptynites (Jastrzębski et al., 2010 and references therein).

These metasedimentary rocks were usually considered as representing the country rocks of magmatic precursors of the gneisses (e.g., Żelaźniewicz, 2005), although, not surprisingly in high-grade contexts, convincing evidence of contact metamorphism has not been found. In fact, the contacts between gneisses and schists have usually a tectonic character (Kozłowski, 1974; Jastrzębski et al., 2010) and might reflect either reworked, originally igneous contacts or purely tectonic structures juxtaposing unrelated units.

Because the primary relationships between schists and magmatic precursors of the gneisses are unknown, relative ages of deposition of the sedimentary protoliths of the mica schists on the one hand, and the igneous emplacement age of the granite precursors on the other hand, can be used to put constraints on possible country rocks of $\sim 500$ Ma metagranites. Taking into account zircon ages, only the dark Stachów gneiss- 

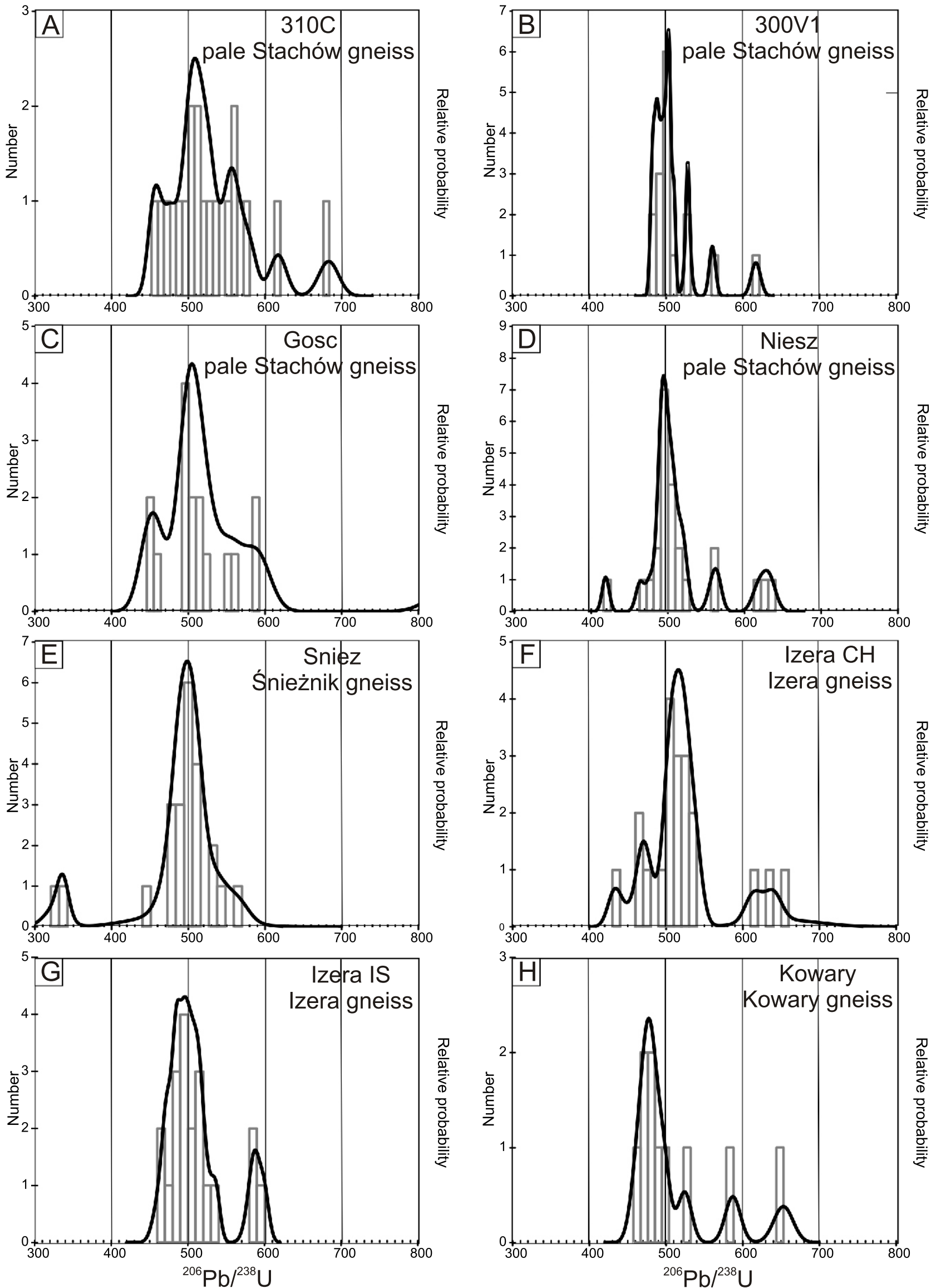

Fig. 12. Distribution of detrital zircon ages $<800$ Ma from the pale Stachów gneisses compared with zircon ages from orthogneisses of the Orlica-Śnieżnik Dome and Karkonosze-Izera Massif, presented as a histogram (group of rectangles) and a cumulative probability plot (black curved line)

Strzelin Massif, pale Stachów gneiss: A - 310C (this study); B - 310V1(this study); C - Gosc (Mazur et al., 2010); D - Niesz (Klimas, 2008); Orlica-Śnieżnik Dome: E - Sniez - Śnieżnik gneiss (Turniak et al., 2000); Karkonosze-Izera Massif; F - Izera CH - Izera gneiss from Chmieleń (Oberc-Dziedzic et al., 2009); G - Izera IS - Izera gneiss from Izerski Stóg (Żelaźniewicz et al., 2009); H - Kowary - Kowary gneiss 

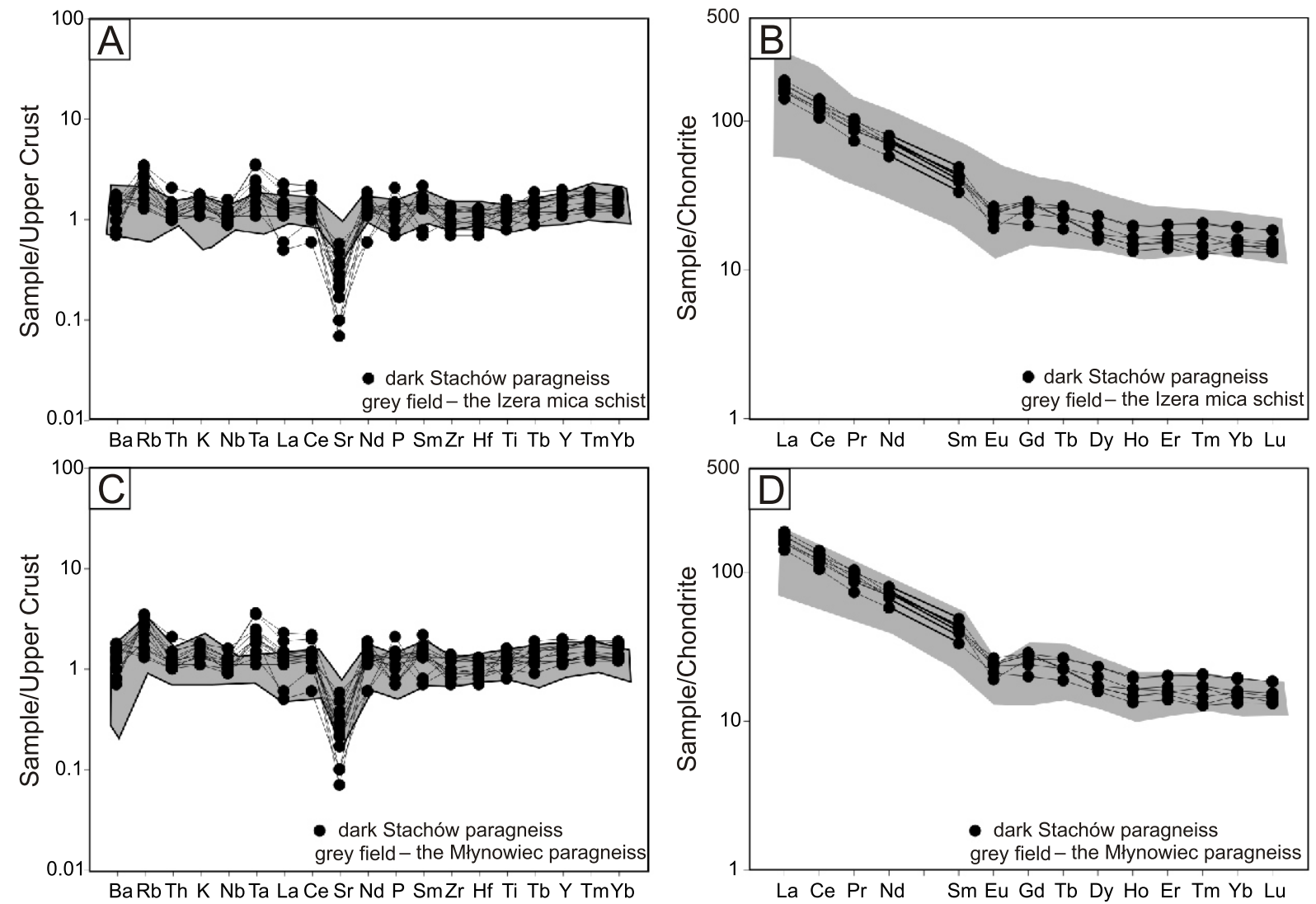

Fig. 13. Upper crust-normalized multi-element diagrams and chondrite-normalized REE plots for the dark Stachów gneiss from the Strzelin Massif

A, B - compared with values of the Izera mica schists (Oberc-Dziedzic et al., 2009); C, D - compared with values of the Młynowiec Formation paragneisses (Szczepański and IInicki, 2014); A-D - trace elements values of dark Stachów gneisses of Madej (2010); A, C - normalization values of Rudnick and Gao (2003); B, D - normalization values of Sun and McDonough (1989)

es, the Złotniki Lubańskie schists occurring in the northern part of the Karkonosze-Izera Massif (Oberc-Dziedzic et al., 2009; Żelaźniewicz et al., 2009), and the Wyszki and Młynowiec paragneisses from the Młynowiec Formation (Jastrzębski et al., 2010; Szczepański and IInicki, 2014; Mazur et al., 2015), which do not contain zircons younger than $500 \mathrm{Ma}$, fulfill the age criteria required to interpret them as possible country rocks of the $\sim 500 \mathrm{Ma}$ granitic intrusions. If this interpretation is correct, the present contacts between these rocks and orthogneisses can be considered as reworked, originally igneous contacts, whereas the contacts between the Izera orthogneisses and the Stara Kamienica schists as well as those between the Śnieżnik orthogneisses and the Stronie Formation rocks are purely tectonic. Such interpretation does not preclude the possibility that rocks of the Złotniki Lubańskie and the Stara Kamienica Belts as well as the Młynowiec and Stronie Formations do not form continuous successions (Jastrzębski et al., 2010), but rather suggests that intrusions of the granitic magmas did not interrupt the sedimentation.

Apart from the age relationships, the bulk proportions between gneisses and metasedimentary rocks and their spatial relationships may also be taken into account in the discussion of their primary relationships. The Izera and Śnieżnik gneisses form bodies considerably larger and less susceptible to deformation than their associated metasedimentary rocks. The contacts between them are probably tectonically modified. In contrast, the pale Stachów gneisses usually form thin (several centimetres to several metres) sheets (easily interpreted as for- mer dykes) within the dark Stachów gneisses (Fig. 4A) and only exceptionally larger stocks. The relative proportions, together with the age of the dark Stachów paragneisses, clearly favour the interpretation that the dark gneisses are country rocks to the pale Stachów orthogneisses. Moreover, the space relationships between the pale and dark Stachów gneisses suggest that they might correspond to the peripheral part of a larger plutonic body possibly similar to the Izera granites, as inferred from the occurrence of bluish K-feldspar in both cases.

The Izera, Śnieżnik, and pale Stachów orthogneisses in the Sudetes show not only the same $\sim 500 \mathrm{Ma}$ age, but also the lithological and geochemical similarity presented earlier by Pin et al. (2007). The comparison of chemical analyses of the pale Stachów gneisses (Oberc-Dziedzic et al., 2016) with data published for the Izera and Śnieżnik gneisses confirm their similarity, previously deduced from only three chemical analyses (Pin et al., 2007).

In order to show the geochemical similarity of metasedimentary rocks accompanying the $\sim 500 \mathrm{Ma}$ orthogneisses, the trace elements of the dark Stachów gneisses (Madej, 2010) were normalized to the upper continental crust and chondrite and compared with the normalized patterns of the Złotniki Lubańskie, Stara Kamienica and Szklarska Poręba belts (Karkonosze-Izera Massif; Oberc-Dziedzic et al., 2009) and the Młynowiec Formation paragneisses (Orlica-Śnieżnik Dome; Szczepański and IInicki, 2014; Fig. 13). The normalization values were taken from Rudnick and Gao (2003) for the upper crust, and from Sun and McDonough (1989) for chondrite. 


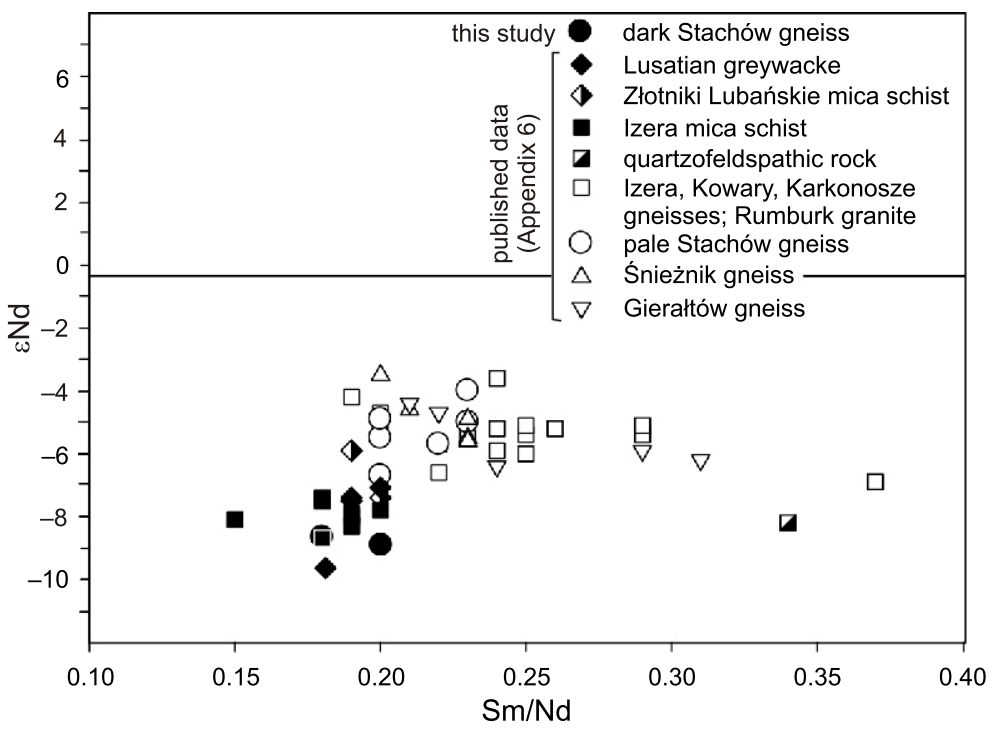

Fig. 14. $\varepsilon \mathrm{Nd}$ versus $\mathrm{Sm} / \mathrm{Nd}$ data compiled for selected metasedimentary rocks and $\sim 500 \mathrm{Ma}$ orthogneisses from the eastern part of the Saxothuringian Terrane

Data sources: dark Stachów gneiss - this study; published data (Appendix 6): Lusatian greywacke - Linnemann and Romer (2002), Oberc-Dziedzic et al. (2009); Złotniki Lubańskie mica schist - Oberc-Dziedzic et al. (2009); Izera mica schist - Crowley et al. (2002), Oberc-Dziedzic et al. (2009); quartzofeldspatic rock - Oberc-Dziedzic et al. (2009); Izera gneiss - Oberc-Dziedzic et al. (2005); Kowary gneiss - Oberc-Dziedzic et al. (2009); Karkonosze gneiss, Rumburk granite - Hegner and Kröner (2000), Kröner et al. (2001); pale Stachów gneiss Oberc-Dziedzic et al. (2016); Śnieżnik gneiss and Gierałtów gneiss - Pin et al. (2007). All $\varepsilon N d$ are recalculated for a 500 Ma age

It can be seen that the normalized patterns are similar. However, the dark Stachów gneisses show higher contents of trace elements and a deeper negative Sr anomaly than the Izera mica schists and the Młynowiec paragneisses (Fig. 13A, C).

The chondrite-normalized REE plot of the dark Stachów gneisses is characterized by a strong LREE enrichment and moderate fractionation of LREE over HREE. Negative Eu anomalies occur in all samples. The REE plots of the Izera mica schists and the Młynowiec paragneisses are similar to those of the dark Stachów gneisses, but the LREE bulk concentration in the dark Stachów gneisses is lower than in the Izera schists (Fig. 13B) and higher than in the Młynowiec paragneisses (Fig. 13D).

Two new Sm-Nd isotope data of the dark Stachów gneisses were compared with 47 published data (Appendix 6). Most published Sm-Nd data (36) were obtained on a subset of samples whose petrographic and geochemical studies were presented in our earlier publications cited in Appendix 6. Some of these samples were also dated by the SHRIMP zircon method. The remaining 11 analyses, concerning mainly (8 of 11) rocks outside the Polish territory, were published by other authors cited in Appendix 6. The ${ }^{147} \mathrm{Sm} /{ }^{144} \mathrm{Nd}$ ratios $(0.1100-0.1269)$ measured in the dark Stachów gneisses are similar to the ratios of the Izera mica schists. As other $\sim 500 \mathrm{Ma}$ orthogneisses of the Saxothuringian Terrane, the pale Stachów gneisses display higher ${ }^{147} \mathrm{Sm} /{ }^{144} \mathrm{Nd}$ ratios $(0.1209-0.1388)$ than the dark gneisses (Appendix 6). The $\varepsilon \mathrm{Nd}_{600}$ values of the dark Stachów gneisses $(-7.4$ and -7.5$)$ are similar to $\varepsilon \mathrm{Nd}_{570}$ values of the Lusatian greywackes $(-8.2$ to -7.1$)$ and the Złotniki Lubańskie schists $(-7.4$ and -5.6$)$ as well as to $\varepsilon \mathrm{Nd}_{500}$ values of the Izera mica schists (-8.7 to -7.5; Appendix 6; Fig. 14).
The initial $\varepsilon N d$ values of the $\sim 100 \mathrm{Ma}$ younger, pale Stachów orthogneisses $\left(-4.9<\varepsilon_{\mathrm{Nd}_{500}}<-6.7\right)$ are similar to those of other $\sim 500$ Ma orthogneisses of the Saxothuringian Terrane (i.e. the Izera, Śnieżnik and Gierałtów gneisses; Appendix 6; Fig. 14).

The average depleted mantle model ages ( $\left.T_{D M}\right)$ of the Lusatian greywackes $1.7 \mathrm{Ga})$, the Izera mica schists $(1.61 \mathrm{Ga})$ and the dark Stachów gneisses $(1.66-1.68 \mathrm{Ga})$ are higher than those of the pale Stachów orthogneisses (1.49-1.67 Ga, up to $1.73 \mathrm{Ga}$ in one sample) and the Śnieżnik orthogneisses (1.39-1.77 Ga), but lower than $\mathrm{T}_{\mathrm{DM}}$ of the Izera gneisses and granites (1.73-1.99 Ga; Appendix 6).

During the Variscan Orogeny, sedimentary rocks accompanying the $\sim 500$ Ma granitoids experienced metamorphism of different degrees: low-grade metamorphism in case of the Złotniki Lubańskie schists (e.g., Oberc-Dziedzic et al., 2009), medium-grade metamorphism in case of the Młynowiec paragneisses (e.g., Jastrzębski et al., 2014) and migmatization in case of the dark Stachów gneisses (Madej, 2010).

The variable deformation conditions during the Variscan Orogeny are reflected in the great variety of deformational structures of orthogneisses. The pale Stachów gneisses usually show intense deformation (Henryków gneisses; Madej, 1999). The most deformed parts of the Izera gneisses represent zones of intense mylonitic deformation. The character of deformation in the Karkonosze-Izera Massif changes from semi-ductile or brittle in the western part of the massif to ductile in its eastern part. A characteristic feature of the Izera gneisses is albitization associated with deformation (e.g., Żelaźniewicz, 2005). The $\sim 500$ Ma granites of the Orlica-Śnieżnik Dome underwent strong deformation and were transformed into the 
Śnieżnik rodding augen gneisses (Żelaźniewicz et al., 2014 and references therein).

Summing up, the $\sim 500$ Ma granitoids and their accompanying sedimentary rocks were metamorphosed under a range of metamorphic conditions (e.g., Chopin et al., 2012; Mazur et al., 2015), increasing from an external zone in the north-west to an internal zone in the south-east.

\section{CONCLUSIONS}

1. The Strzelin Massif comprises two metamorphic complexes: (1) the authochthonous (or parauthochthonous) Strzelin Complex that is part of the Brunovistulicum, and (2) the allochthonous Stachów Complex, composed of the Early Ordovician ( 500 Ma) orthogneisses (the pale Stachów gneisses) and the metasedimentary dark Stachów gneisses.

2. The ages of the inherited zircons of the pale Stachów gneisses suggest that the source materials for their granitic pre- cursors were of Armorican affinity. Such provenance of granitic sources is characteristic for the Saxothuringian Terrane.

3. The age similarity of zircons from the dark Stachów gneisses and those of other metasedimentary rocks associated with the $\sim 500 \mathrm{Ma}$ orthogneisses suggests that they also belong to the Saxothuringian Terrane.

4. The pale and dark Stachów gneisses show also geochemical similarity to the $\sim 500 \mathrm{Ma}$ orthogneisses and accompanying metasedimentary rocks from other parts of the Saxothuringian Terrane.

5. The differences in metamorphic grade of the metasedimentary rocks accompanying the $\sim 500$ Ma orthogneisses, and the great variety of deformational structures of the orthogneisses suggest that they belong to different structural units of a tectonic stack.

Acknowledgements. We thank K. Dymna for zircon separation. An anonymous reviewer and Dr. hab. M. Jastrzębski are thanked for their detailed and constructive reviews. The investigations were performed within the Project N307 008 32/0314 of the Ministry of Science and Higher Education.

\section{REFERENCES}

Aleksandrowski, P., Mazur, S., 2002. Collage tectonics in the northeasternmost part of the Variscan Belt: the Sudetes, Bohemian Massif. Geological Society Special Publications, 201: 237-277.

Badura, J., 1979. Szczegółowa mapa geologiczna Sudetów, arkusz Stolec 1:25 000. Wyd. Geol., Warszawa.

Bederke, E., 1931. Die moldanubische Überschiebung im Sudetenvorlände. Zentralblatt für Mineralogie, Geologie und Paläontologie, Abt. B: 349-408.

Białek, D., Kryza, R., Oberc-Dziedzic, T., Pin, C., 2014. Cambrian Zawidów granodiorites in the Cadomian Lusatian Massif (Central European Variscides): what do the SHRIMP zircon ages mean? Journal of Geosciences, 59: 313-326.

Black, L.P., Kamo, S.L., Allen, C.M., Aleinikoff, J.N., Davis, D.W., Korsch, R.J., Foudoulis, C., 2003. TEMORA 1: a new zircon standard for Phanerozoic U-Pb geochronology. Chemical Geology, 200: 155-170.

Chlupáč, I., 1975. New finds of fauna in the metamorphic Devonian of the Hruby Jeseník Mts. (Moravia, Czechoslovakia) (in Czech with English summary). Časopis pro mineralogie a geologie, 20: 259-268.

Chopin, F., Schulmann, K., Skrzypek, E., Lehmann, J., Dujardin, J.R., Martelat, J.E., Lexa, O., Corsini, M., Edel, J.B., Štípská, P., Pitra, P., 2012. Crustal influx, indentation, ductile thinning and gravity redistribution in a continental wedge: building a Moldanubian mantled gneiss dome with underthrust Saxothuringian material (European Variscan belt). Tectonics, 31, TC1013, doi:10.1029/2011TC002951

Crowley, Q.G., Timmermann, H., Noble, S.R., Holland, J.G., 2002. Palaeozoic terrane amalgamation in Central Europe: a REE and Sm-Nd isotope study of the pre-Variscan basement, NE Bohemian Massif. Geological Society Special Publications, 201: 157-176.

Cymerman, Z., Piasecki, M.A.J., Seston, R., 1997. Terranes and terrane boundaries in the Sudetes, northeast Bohemian Massif. Geological Magazine, 134: 717-725.

Dudek, A., 1980. The crystalline basement block of the Outer Carpathians in Moravia: Bruno-Vistulicum. Rozpravy České Akademie Věd, Řada matematických a přirodnich Véd, 90 $1-85$.
Franke, W., 1989. Tectonostratigraphic units in the Variscan belt of Central Europe. GSA Special Papers, 230: 67-89.

Franke, W., 2000. The mid-European segment of the Variscides: tectonostratigraphic units, terrane boundaries and plate tectonic evolution. Geological Society Special Publications, 179: 35-61.

Franke, W., 2012. Comment on Dörr and Zulauf: Elevator tectonics and orogenic collapse of a Tibetan-style plateau in the European Variscides: the role of the Bohemian shear zone. International Journal of Earth Sciences, 101: 2027-2034.

Franke, W., Żelaźniewicz, A., 2000. The eastern termination of the Variscides: terrane correlation and kinematic evolution. Geological Society Special Publications, 179: 63-86.

Friedl, G., Finger, F., McNaughton, N.J, Flechter, I.R., 2000. Deducing the ancestry of Terranes: SHRIMP evidence for South America-derived Gondwana fragments in central Europe. Geology, 28: 1035-1038.

Hegner, E., Kröner, A., 2000. Review of $\mathrm{Nd}$ isotopic data and xenocrystic and detrital zircon ages from the pre-Variscan basement in the eastern Bohemian Massif: speculations on the palinspastic reconstruction. Geological Society Special Publications, 179: 113-129.

Jastrzębski, M., Żelaźniewicz, A., Nowak, I., Murtezi, M., Larionov, A.N., 2010. Protolith age and provenance of rocks in Variscan allochthon units: U-Pb SHRIMP zircon data from the Orlica-Śnieżnik Dome, West Sudetes. Geological Magazine, 147: $416-433$

Jastrzębski, M., Stawikowski, W., Budzyń, B., Orłowski, R., 2014. Migmatization and large-scale folding in the Orlica-Śnieżnik Dome, NE Bohemian Massif: Pressure-temperature-time-deformation constraints on Variscan terrane assembly. Tectonophysics, 630: 54-74.

Klimas, K., 2008. Geochronology and petrogenetical study of zircons from selected crystalline rocks in the eastern part of the Fore-Sudetic Block (in Polish with English summary). Uniwersytet Wrocławski, Instytut Nauk Geologicznych, Wrocław.

Kossmat, F., 1927. Gliederung des varistischen Gebirgsbaues. Abhandlungen Sächsischen Geologischen Landesamts, 1: $1-39$. 
Kozłowski, K., 1974. Crystalline schists and leucogranites of the Stara Kamienica-Świeradów Zdrój Belt (in Polish with English summary). Geologia Sudetica, 9: 7-100.

Kröner, A., Jaeckel, P., Hegner, E., Opletal, M., 2001. Single zircon ages and whole-rock $\mathrm{Nd}$ isotopic systematics of early Palaeozoic granitoid gneisses from the Czech and Polish Sudetes (Jizerské hory, Krkonoše Mountains and Orlice-Snežník Complex). International Journal of Earth Sciences, 90: 304-324.

Kryza, R., Zalasiewicz, J., Mazur, S., Aleksandrowski, P., Sergeev, S., Larionov, A., 2007. Precambrian crustal contribution to the Variscan accretionary prism of the Kaczawa Mountains (Sudetes, SW Poland): evidence from SHRIMP dating of detrital zircons. International Journal of Earth Sciences, 96 1153-1162.

Larionov, A.N., Andreichev, V.A., Gee, D.G., 2004. The Vendian alkaline igneous suite of northern Timan: ion microprobe $\mathrm{U}-\mathrm{Pb}$ zircon ages of gabbros and syenite. Geological Society Memoirs, 30: $69-74$.

Linnemann, U., Romer, R.L., 2002. The Cadomian Orogeny in Saxo-Thuringia, Germany; geochemical and $\mathrm{Nd}-\mathrm{Sr}-\mathrm{Pb}$ isotopic characterization of marginal basins with constraints to geotectonic setting and provenance. Tectonophysics, 352: 33-64.

Linnemann, U., McNaughton, N.J., Romer, R.L., Gehmlich, M., Drost, K., Tonk, C., 2004. West African provenance for Saxo-Thuringia (Bohemian Massif): did Armorica ever leave pre-Pangean Gondwana? - U/Pb-SHRIMP zircon evidence and the Nd-isotopic record. International Journal of Earth Sciences, 93: 683-705.

Linnemann, U., Gerdes, A., Drost, K., Buschmann, B., 2007. The continuum between Cadomian Orogenesis and opening of the Rheic Ocean: constraints from LA-ICP-MS U-Pb zircon dating and analysis of plate-tectonic setting (Saxo-Thuringian Zone NE Bohemian Massif, Germany). GSA Special Paper, 423: 61-96.

Ludwig, K.R., 2005a. SQUID 1.12 A User's Manual. A Geochronological Toolkit for Microsoft Excel. Berkeley Geochronology Center Special Publication, 1-22, http://www.bgc.org/klprogrammenu.html

Ludwig, K.R., 2005b. User's Manual for ISOPLOT/Ex 3.22. A Geochronological Toolkit for Microsoft Excel. Berkeley Geochronology Center Special Publication, 1-71, http://www.bgc.org/klprogrammenu.html

Madej, S., 1999. Extensional tectonics in the eastern part of the Fore-Sudetic Block: evidence from the Henryków gneiss. Mineralogical Society of Poland Special Papers, 14: 38-41.

Madej, S., 2010. Petrology and tectonics of gneisses from the Lipowe Hills (the Fore-Sudetic Block). Ph.D thesis (in Polish)

Matte, P., Maluski, H., Rajlich, P., Franke, W., 1990. Terrane boundaries in the Bohemian Massif: results of large-scale Variscan shearing. Tectonophysics, 177: 151-170.

Mazur, S., Aleksandrowski, P., Kryza, R., Oberc-Dziedzic, T., 2006. The Variscan Orogen in Poland. Geological Quarterly, 50 (1): 89-118

Mazur, S., Kröner, A., Szczepański, J., Turniak, K., Hanžl, P., Melichar, R., Rodionov, N.V., Paderin, I., Sergeev, S.A., 2010 Single zircon U-Pb ages and geochemistry of granitoid gneisses from SW Poland: evidence for an Avalonian affinity of the Brunian microcontinent. Geological Magazine, 147: 508-526.

Mazur, S., Szczepański, J., Turniak, K., McNaughton, N.J., 2012. Location of the Rheic suture in the eastern Bohemian Massif: evidence from detrital zircon data. Terra Nova, 24: 199-206.

Mazur, S., Turniak, K., Szczepański, J., McNaughton, N.J., 2015 Vestiges of Saxothuringian crust in the Central Sudetes, Bohemian Massif: zircon evidence of a recycled subducted slab provenance. Gondwana Research, 27: 825-839.

Oberc, J., 1966. Geology of crystalline rocks of the Wzgórza Strzelińskie Hills, Lower Silesia (in Polish with English summary). Studia Geologica Polonica, 20: 1-187.
Oberc, J., 1972. Sudety i obszary przyległe. In: Budowa geologiczna Polski, 4. Tektonika, 2. Instytut Geologiczny, Warszawa.

Oberc-Dziedzic, T., 1995. Research problems of the Wzgórza Strzelińskie metamorphic series in the light of borehole materials (in Polish with English summary). Acta Universitatis Wratislaviensis, 1739, Prace Geologiczno-Mineralogiczne, 50: 77-103.

Oberc, J., Oberc-Dziedzic, T., Klimas-August, K., 1988. Mapa geologiczna Wzgórz Strzelińskich (1:25 000) (in Polish). Instytut Nauk Geologicznych Uniwersytetu Wrocławskiego, Przedsiębiorstwo Geologiczne, Wrocław.

Oberc-Dziedzic, T., Kryza, R., 2012. Late stage Variscan magmatism in the Strzelin Massif (SW Poland): SHRIMP zircon ages of tonalite and Bt-Ms granite of the Gęsiniec intrusion. Geological Quarterly, 56 (2): 225-236.

Oberc-Dziedzic, T., Madej, S., 2002. The Variscan overthrust of the Lower Palaeozoic gneiss unit on the Cadomian basement in the Strzelin and Lipowe Hills massifs, Fore-Sudetic Block, SW Poland; is this part of the East-West Sudetes boundary? Geologia Sudetica, 34: 39-58.

Oberc-Dziedzic, T., Kryza, R., Klimas, K., Fanning, M.C., Madej, S., 2005a. Gneiss protolith ages and tectonic boundaries in the NE part of the Bohemian Massif (Fore-Sudetic Block, SW Poland). Geological Quarterly, 49 (4): 363-378.

Oberc-Dziedzic, T., Pin, C., Kryza, R., 2005b. Early Palaeozoic crustal melting in an extensional setting: petrological and $\mathrm{Sm}-\mathrm{Nd}$ evidence from the Izera granite-gneisses, Polish Sudetes. International Journal of Earth Sciences, 94: 354-368.

Oberc-Dziedzic, T., Kryza, R., Pin, C., Mochnacka, K., Larionov, A., 2009. The Orthogneiss and Schist Complex of the Karkonosze-Izera Massif (Sudetes, SW Poland): U-Pb SHRIMP zircon ages, Nd-isotope systematics and protoliths. Geologia Sudetica, 41: 3-24.

Oberc-Dziedzic, T., Kryza, R., Mochnacka, K., Larionov, A., 2010. Ordovician passive continental margin magmatism in the Central-European Variscides: U-Pb zircon data from the SE part of the Karkonosze-Izera Massif, Sudetes, SW Poland. International Journal of Earth Sciences, 99: 27-46.

Oberc-Dziedzic, T., Pin, C., Madej, S., Kryza, R., 2016. Three generations of granitoids emplaced over a 300 My time span in the Strzelin Massif, Fore-Sudetic Block, SW Poland: mutual relationships and implications for secular crustal evolution. Journal of Geosciences, 61: 289-308.

Oliver, G.J.H., Corfu, F., Krough, T.E., 1993. U-Pb ages from SW Poland: evidence for a Caledonian suture zone between Baltica and Gondwana. Journal of the Geological Society, 150: 355-369.

Pin, C., Rodriguez, J., 2009. Comment on "Rheic Ocean ophiolitic remnants in southern Iberia questioned by SHRIMP U-Pb zircon ages on the Beja-Acebuches amphibolites" by A. Azor et al., Tectonics, 28, TC5013, doi:10.1029/2009TC002495

Pin, C., Santos Zalduegui, J., 1997. Sequential separation of light rare earth elements, thorium and uranium by miniaturized extraction chromatography: application to isotopic analyses of silicate rocks. Analytica Chimica Acta, 339: 79-89.

Pin, C., Kryza, R., Oberc-Dziedzic, T., Mazur, S., Turniak, K. Waldhausrová, J., 2007. The diversity and geodynamic significance of Late Cambrian (ca. $500 \mathrm{Ma}$ ) felsic anorogenic magmatism in the northern part of the Bohemian Massif: a review based on $\mathrm{Sm}-\mathrm{Nd}$ isotope and geochemical data. GSA Special Paper, 423: 209-229.

Redlińska-Marczyńska, A., Żelaźniewicz, A., Fanning, C.M., 2016. An insight into a gneiss core of the Orlica-Śnieżnik Dome, NE Bohemian Massif: new structural and U-Pb zircon data. Geological Quarterly, 60 (3): 714-736.

Rudnick, R.J., Gao, S., 2003. Composition of the continental crust, pp. 1-64. In: The crust (ed. R.J. Rudnick), 3. Treatise on Geochemistry (eds. H.D. Holland and K.K. Turekian). Elsevier-Pergamon, Oxford. 
Stacey, J.S., Kramers, J.D., 1975. Approximation of terrestrial lead isotope evolution by a two-stage model. Earth and Planetary Science Letters, 26: 207-221.

Steiger, R.H., Jäger, E., 1977. Subcommission on geochronology: convention on the use of decay constants in geo- and cosmochronology. Earth and Planetary Science Letters, 36 359-362.

Suess, F.E., 1912. Die moravischen Fenster und ihre Beziehung zum Grundgebirge des Hohen Gesenke. Denkschriften Österreich, Akademie zur Wissenschaft, MathematischNaturwissenschaftliche Klasse, 88: 541-631.

Sun, S.S., McDonough, W.F., 1989. Chemical and isotopic systematics of oceanic basalts: implications for mantle composition and processes. Geological Society Special Publications, 42 313-345.

Szczepański, J., Ilnicki, S., 2014. From Cadomian arc to Ordovician passive margin: geochemical records preserved in metasedimentary successions of the Orlica-Śnieżnik Dome in SW Poland. International Journal of Earth Sciences, 103: 627-647.

Tait, J.A., Bachtadse, V., Franke, V., Soffel, H.C., 1997. Geodynamic evolution of the European Variscan fold belt: palaeomagnetic and geological constraints. Geologische Rundschau, 86: 585-598.

Turniak, K., Mazur, S., Wysoczanski, R., 2000. SHRIMP zircon geochronology and geochemistry of the Orlica-Śnieżnik gneisses (Variscan belt of Central Europe) and their tectonic implications. Geodinamica Acta, 13: 293-312.

Whitney, D.L., Evans, B.W., 2010. Abbreviations for names of rock-forming minerals. American Mineralogist, 95: 185-187.
Wiedenbeck, M., Allé, P., Corfu, F., Griffin, W.L., Meier, M., Oberli, F., Von Quadt, A., Roddick, J.C., Spiegel, W., 1995. Three natural zircon standards for U-Th-Pb, Lu-Hf, trace element and REE analyses. Geostandards Newsletter, 19: 1-23.

Williams, I.S., 1998. U-Th-Pb geochronology by ion microprobe. In: Applications in microanalytical techniques to understanding mineralizing processes. Reviews in Economic Geology, 7: 1-35.

Wójcik, L., 1968. Szczegółowa mapa geologiczna Sudetów, arkusz Ciepłowody 1:25 000. Wyd. Geol., Warszawa.

Wroński, J., 1973. Szczegółowa mapa geologiczna Sudetów, arkusz Ziębice 1:25 000. Wyd. Geol., Warszawa.

Žáčková, E., Konopásek, J., Košler, J., Jeřábek, P., 2012. Detrital zircon populations in quartzites of the Krkonoše-Jizera Massif: implications for pre-collisional history of the Saxothuringian Domain in the Bohemian Massif. Geological Magazine, 149: 443-458.

Żelaźniewicz, A., 2005. Przeszłość geologiczna (in Polish). In: Przyroda Dolnego Ślaska (ed. J. Fabiszewski): 61-134. PAN Wrocław.

Żelaźniewicz, A., Fanning, C.M., Achramowicz, S., 2009. Refining the granite, gneiss and schist interrelationships within the Lusatian-Izera Massif, West Sudetes, using SHRIMP U-Pb zircon analyses and new geologic data. Geologia Sudetica, 41: 67-84.

Żelaźniewicz, A., Jastrzębski, M., Redlińska-Marczyńska, A., Szczepański, J., 2014. Orlica-Śnieżnik Dome, the Sudetes, in 2002 and 12 years later. Geologia Sudetica, 42: 105-123. 